\title{
A Proposed Framework to Analyze the Impact Investing Ecosystem in a Cross-Country Perspective*
}

\author{
Juan David Rivera Acevedo ${ }^{1} \&$ Min-ni Wu ${ }^{2}$ \\ ${ }^{1}$ Juan David Rivera Acevedo, Center for Empirical Research in Economics and Behavioral Science (CEREB) at the \\ University of Erfurt, Germany \\ ${ }^{2}$ Min-ni Wu, Willy Brandt School of Public Policy at the University of Erfurt, Germany \\ Correspondence: Juan David Rivera Acevedo, Center for Empirical Research in Economics and Behavioral Science \\ (CEREB) at the University of Erfurt, Germany. E-mail: juan_david.rivera_acevedo@uni-erfurt.de
}

Received: July 11, 2018 Accepted: August 28, 2018 Online Published: September 17, 2018

doi:10.5539/res.v10n4p87 URL: https://doi.org/10.5539/res.v10n4p87

\begin{abstract}
This study developed an impact investing ecosystem framework to present a comprehensive overview of the impact investing sector, identifying key challenges and possibilities. Two Asian countries, Japan and Singapore, were used as case studies. The proposed framework revealed that the market scales in Japan and Singapore were small and each country faces unique challenges for developing impact investing. For Japan, the low level of philanthropic activities and the small social sector were the key challenges to overcome for impact investing growth. For Singapore, the government's low social expending strategy may limit the development. However, both countries have supportive environments for impact investing due to high-quality human resources, well-developed financial markets and political interest. In particular, the high total wealth of high network individuals (HNWI) in Japan and large donations to charities in Singapore (\% GDP) offer rich potential.
\end{abstract}

Keywords: entrepreneurial ecosystem, impact investing, public policy, social impact investment framework, social impact bonds

\section{Introduction}

New approaches to address increasing social challenges are necessary, especially as national economies develop and additional strain is placed on social and environmental demands. Pollution, natural resource exhaustion, income inequality, and increasing healthcare costs are new problems requiring attention across the globe. While the challenges are growing, the traditional solutions from the public sector that have been relied upon are insufficient - many governments are debt-ridden, and charities and non-profit organizations (NPOs) continue to struggle to raise funds. In this context, impact investing has emerged as an innovative cross-sector arrangement to support the work of the social sector while still generating financial revenue. In this process, impact investors provide capital to social-purpose organizations (SPOs), aiming at creating both financial and social returns (Bugg-Levine \& Emerson, 2011; Nicholls, 2010).

During the past decade, efforts have been made to build a formal impact investing industry at a global level. Market infrastructures, networks, platforms, and methods to measure social impacts have been established (Jackson, 2013). In addition, academic research has provided empirical evidence that impact investing has been successfully implemented in a wide range of forms (Ormiston, Charlton, Donald, \& Seymour, 2015). Governmental institutions, such as the European Commission and G8 countries (now G7) led by the United Kingdom, have shown their support (European Commission, 2011; Social Impact Investment Taskforce [SIITF], 2014). The emergence of impact bonds has also actively included public capital in the practice of impact investing. Across the globe, there are currently 89 impact bonds being implemented and capital amounting to USD 322 million has been raised for the projects (Social Finance UK, 2017).

Despite the attention and support, more commitment is needed to stimulate the development of impact investing globally. Geographically, the major actors in the impact investing market are based in Europe and North America (Jackson, 2013). In Asia, where impact investing is a relatively new concept, only a few players are involved (Asian Development Bank,

\footnotetext{
"An early version of this paper was presented at the 24th International Scientific Conference on Economic and Social Development - "Managerial Issues in Modern Business" in Warsaw on 13-14 October 2017 under the name of "The Impact Investing Ecosystem in Japan and Singapore"
} 
2011). There is very limited academic literature focusing on this topic. As the structure and function of the social sector vary across different countries, a further contextual examination is necessary, particularly with regard to Asia. Therefore, the primary attempt of this research is to propose a framework to assess and compare the impact investing ecosystems in a cross-country perspective, considering the role of public policy in the development of the market, and then offering policy recommendations. For this purpose, this research applies an entrepreneurial ecosystem approach (based on the Babson Entrepreneurship Ecosystem Project (BEEP)) and adapts it to the context of impact investing based on the Social Impact Investment Framework from the Organization for Economic Co-operation and Development (OECD). With this approach, a comprehensive overview of the development is presented, possibilities and challenges of impact investing are identified, and the key determinants are evaluated. Japan and Singapore are used as case studies, and the highly developed UK impact investing market is used as a benchmark for policies and strategies concerning market development.

This paper is organized into four sections: the first section explains the concept of impact investing and provides the theoretical framework for the proposed social impact investing framework. The second section presents the six domains of the framework, and the methodology used to select the indicators for evaluating the ecosystem in the selected countries. The third section analyzes and interprets the relevant findings to answer the research questions: What are the current developments of impact investing in Asia? Who are the main actors in the market? What are the possibilities and challenges? How can public policy enable the development of impact investing? The fourth section presents the conclusions and policy recommendations for each country individually.

\section{Theoretical Framework}

\section{Impact Investing}

The term "impact investing" was coined in 2007 by the Rockefeller Foundation (Harji \& Jackson, 2012). It presents a new investment logic that has gained growing attention over the past decade - the impact investors provide capital to social entrepreneurs, actively aiming at creating measurable social changes with the goal of obtaining financial returns as well (Bugg-Levine \& Emerson, 2011; Jackson, 2013; Nicholls, 2010). Following this model, various investment activities have emerged across the globe.

Impact investing is a new political-economic arrangement between the government, business, and social sectors. More concretely, it emerged alongside three major trends. Firstly, it is related to an attitude change toward new capitalism (M.T. Dacin, P. A. Dacin, \& Tracey, 2011; Clark, Emerson, \& Thornley, 2014). Society now requires a more sustainable and ethical way to develop the economy. For example, consumers in the newer generations demand "good" products that are environmentally and socially ethical (Herman, 2010; Nicholls \& Opal, 2005). This change of attitude has stimulated the practice of impact investing, giving financial incentives for investors to create social values. Secondly, impact investing is seen as the evolution of Corporate Social Responsibility (CSR) and Socially Responsible Investing (SRI) movements (Ormiston et al., 2015). The third trend that contributes to impact investing is the change in the social sector. During the past decades, the social sector has begun to adopt and adapt business techniques in order to address social problems, generating revenue to be more self-sustaining; accordingly, social enterprises have emerged (Borzaga \& Defourny, 2001, 2004; Seelos \& Mair, 2005; Volkmann, Tokarski, \& Ernst, 2012). These developments shaped the modern social sector in a way that resembles market economies and created investing opportunities for impact investors.

These trends show that impact investing serves as a cross-sector collaborative approach that can create mutual benefits for all three participating parties. For governments, it helps them solve social problems; for private investors, it responds to the demands of consumers and creates financial benefits; and for the social sector, it provides needed resources and improves their effectiveness.

The impact investing sector is still young and faces several challenges, including a lack of sufficient capital and high-quality investment opportunities (Wilson, Silva, \& Ricardson, 2015; Achleitner, Heinecke, Noble, Schöning, \& Spiess-Knafl, 2011), and the need of more enabling environments, effective intermediaries, and proper legal frameworks for further growth (Bugg-Levine \& Goldstein, 2009; Mendell \& Barbosa, 2013; Wilson et al., 2015). To overcome these challenges, more governmental involvement is recommended to shape and boost the market (Mendell \& Barbosa, 2013; Moore, Westley, Tjornbo, \& Holroyd, 2012b; Sunley \& Pinch, 2012; Wood, Thornley, \& Grace, 2013). Furthermore, a more tailored academic engagement is needed to support the design of effective interventions. Research has yet to theorize on the investment structure and clearly define the epistemological boundaries (Moore, Westley, \& Nicholls, 2012a). Despite Nicholls' (2010) significant contribution to conceptualize impact investments and examine the investment logic and rationality, impact investing requires further conceptual clarification. At this early stage of development, researchers have diverse understandings of the notion and difficulty providing a precise definition (Höchstädter \& Scheck, 2015; Moore et al., 2012a; Wilson et al., 2015). Furthermore, there is a wide range of related terms to describe impact investing that are utilized interchangeably or with overlapping concepts (Louche, Arenas, \& Cranenburgh, 2012; Wilson et al., 2015; Wood \& Hagerman, 2010). The most common ones are social investing and 
socially responsible investing (SRI) (Höchstädter \& Scheck, 2015). Despite the use of different terms, the concepts do not differ from impact investing fundamentally (Louche et al., 2012; Wilson et al., 2015; Wood \& Hagerman, 2010). The term "social investing" emerged earlier in 2000 and is commonly used in Europe in line with impact investing. It usually covers a broader meaning and includes all investing actions with a social or environmental purpose (Höchstädter \& Scheck, 2015; Wilson et al., 2015). The term "SRI" is used to describe a more traditional view of ethical or sustainable investing (Höchstädter \& Scheck, 2015). For our research purposes, the two terms are included in the discussion of impact investing, in an attempt to cover the full potential of its development.

According to the literature review, the general definition of impact investing centers on three core elements: the creation of both social and financial returns, the intention, and measurable impacts. Namely, investors intentionally provide capital to organizations to generate a "blended value" of both social impacts and financial profits (Höchstädter \& Scheck, 2015; Nicholls, 2010). The idea of blended value creation attempts to focus on both of these outcomes without trade-offs (Emerson, 2003), and this idea represents what impact investing aims to achieve (Bugg-Levine \& Emerson, 2011). While discussions of impact investing highlight the intention and measurement of social impacts, the level of financial return rates is usually not limited and the investors can adopt different investment strategies (Höchstädter \& Scheck, 2015; Nicholls, 2010). This research is based on this general understanding of impact investing. In this context, impact investing can be practiced in a wide range of forms to address social or environmental issues wherever needed. Firstly, impact investing can appear in the form of debt, equity, loans, microfinance funds, venture philanthropy, or hybrid capital (Achleitner et al., 2011; Bugg-Levine \& Emerson, 2011; Ormiston et al., 2015). In other words, impact investors can choose from a broad spectrum of investment strategies for any combination of social and financial risks and returns, according to their investing interest and rationality (Nicholls, 2010; Rangan, Appleby, \& Moon, 2011; SIITF, 2014). As a consequence, the flexibility and diversity of strategic options in the impact investing market attract various types of investors seeking social and/or environmental impact plus profit.

\section{The OECD Social Impact Investment Framework}

To explore the landscape of impact investing and the role public policy can play in catalyzing its development, a comprehensive understanding of the actors and influencing factors in the impact investing industry is necessary. Because the impact investing market is nascent, the focus of the academic field is usually on measuring the impact of value creation rather than evaluating the entire impact investing market (Jackson, 2013). Hence, there are limited approaches available for the analysis of current developments. The OECD provides the most systemic approach.

As shown in Figure 1, the Social Impact Investment Framework by the OECD presents the elements that make up the social impact investment market (Wilson et al., 2015). It provides a clear overview of the impact investing industry as an "ecosystem", identifying the relevant actors, investing channels and influencing factors in the market. This concept closely corresponds to this study's goal to explore the scale and size of the impact investing market in a cross-country perspective. Nevertheless, the framework combines different types of key factors under the same category "enabling environment". Given that this research attempts to explore the impact investing industry for policy-makers, it is essential to examine these core enabling environment conditions in a more organized way, avoiding omissions and without too much focus on the investors, investees, and intermediaries. Therefore, this research reorganized the elements of this framework based on an associated entrepreneurial ecosystem approach.

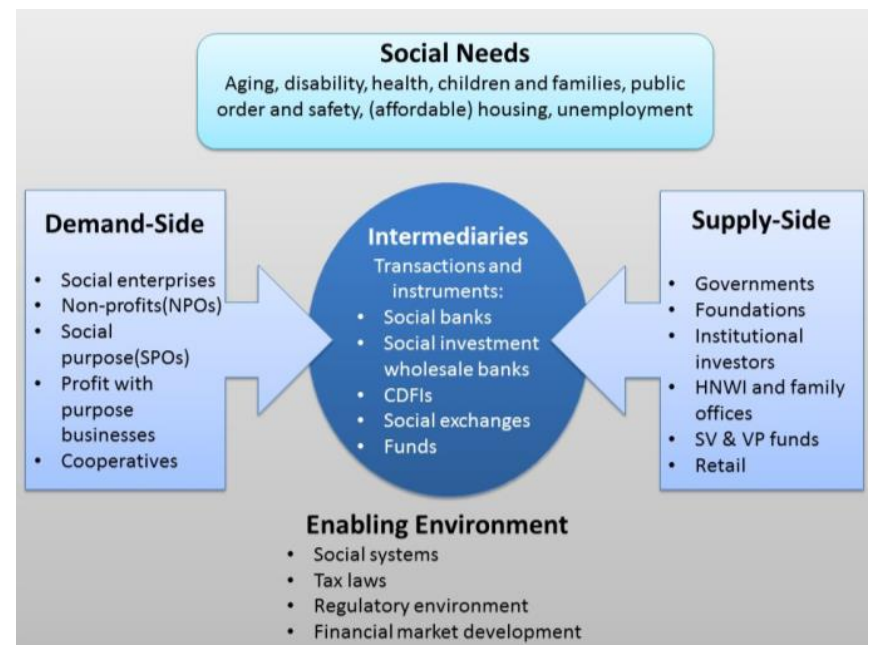

Figure 1. OECD’s Social Impact Investment Framework

Source: Authors, adapted from Wilson et al., 2015. 


\section{The Entrepreneurial Ecosystem Approach}

Since the OECD framework to examine the impact investing industry is limited, this research paper explores the ecosystem approach utilized in the field of entrepreneurship creation. The entrepreneurial ecosystem approach provides a comprehensive method to examine, support, or stimulate entrepreneurship. It studies the creation of new businesses in a region as the outcome of a self-sustaining entrepreneurial ecosystem with a unique environment, consisting of various interacting components (Isenberg \& Onyemah, 2016; Neck, Meyer, Cohen, \& Corbett, 2004; Stam, 2015). A healthy entrepreneurial ecosystem is believed to lead to job creation and economic growth (Neck et al., 2004; Stam, 2015). For public policy, this approach presents a holistic and systemic view, focusing on enabling a self-sustaining ecosystem that leads to entrepreneurship growth instead of intervening in the business of particular entrepreneurs (Ács, Autio, \& Szerb, 2014; Autio, Kenney, Mustar, Siegel, \& Wright, 2014; Mason \& Brown, 2014; Stam, 2015). Measuring the existing ecosystem could provide a comprehensive overview of the enabling actors, the possible challenges, and opportunities. Hence, mapping the ecosystem could be the first step towards encouraging entrepreneurial actions.

This approach was chosen for the following reasons. First, the impact investing sector resembles traditional entrepreneurship activities as it involves the creation of both social and financial values. By considering impact investing an emerging new sector of entrepreneurship, this approach is suitable to help understand current developments, identify the actors, potential and challenges in the market, and consequently provide the information required to design suitable policies. In addition, the concept of examining entrepreneurship like an ecosystem has similarities to the Social Impact Investing Framework developed by the OECD. Lastly, previous research has also applied a broader ecosystem approach in the field of modern economics for various sectors with different scopes and objectives (Adner, 2017; Cohen, 2006; Ferdinand \& Meyer, 2017; Fraiberg, 2017; Park \& Choi, 2014).

This study utilized the entrepreneurial ecosystem framework from the Babson Entrepreneurship Ecosystem Project (BEEP). As presented in Figure 2, the BEEP identifies the key components of the entrepreneurial ecosystem by categorizing them into six domains: policy, markets, human capital, culture, supports, and finance (Isenberg \& Onyemah, 2016). These elements form an interactive and self-sustaining environment that leads to entrepreneurship growth (Isenberg \& Onyemah, 2016). The BEEP framework was chosen because it focuses more on the interacting actors and factors instead of measuring their performances and impacts, which is more suitable for the industry in an early stage of development. Moreover, it is more general and conceptual, as it does not utilize a defined set of indicators. This allows for more flexibility in the selection of proper indicators, which is necessary given the nature of the impact investing industry.
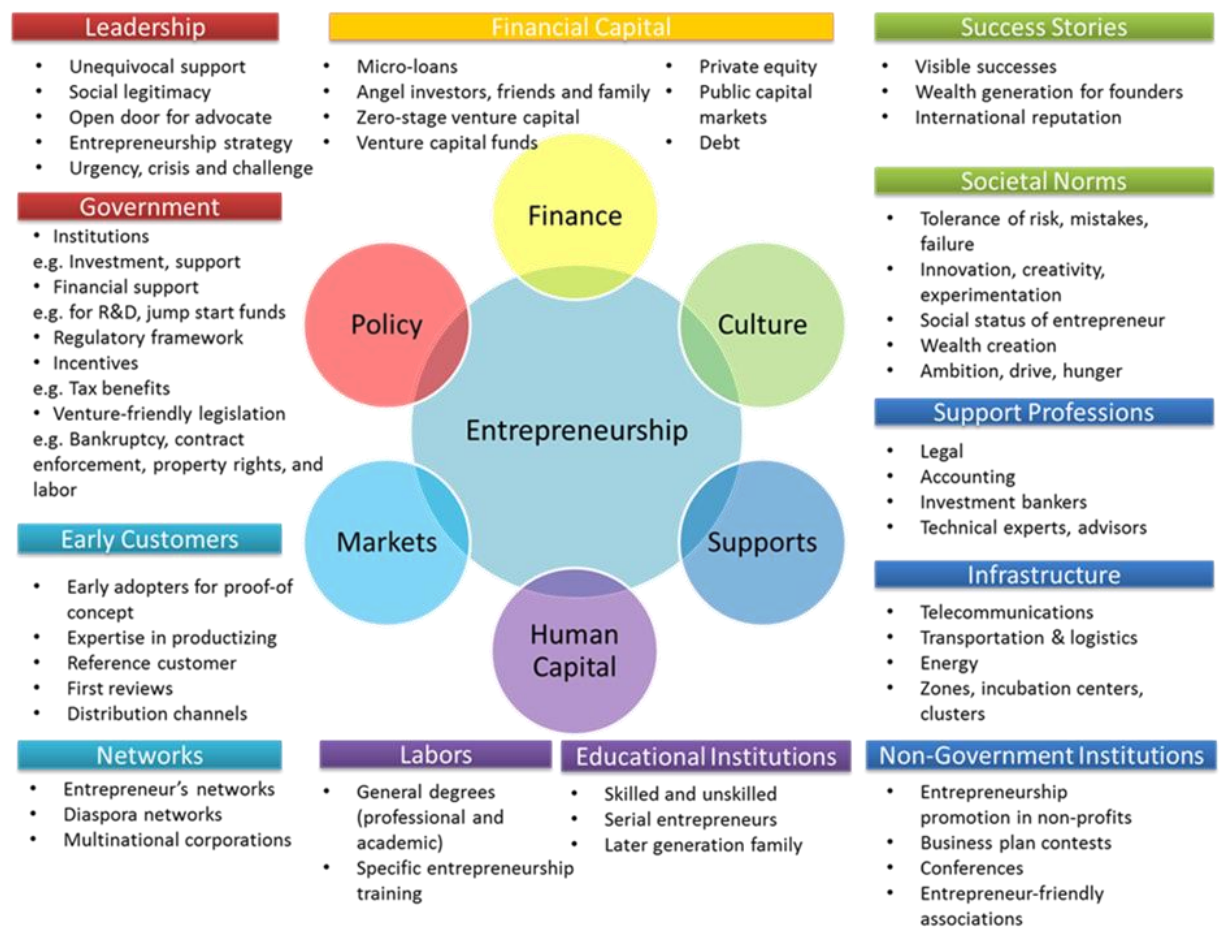

Figure 2. BEEP: Components of the Ecosystem

Source: Authors, adapted from Isenberg \& Onyemah, 2016. 
Isenberg (2016), the head of the BEEP project, argued that the entrepreneurship ecosystem should be observed in small geographic units

${ }^{2}$ because some components of the framework are linked to culture (e.g. risk aversion, ambition, creativity, etc.), which differs across regions. However, studies focusing on national systems of entrepreneurship exist as well (see Ács et al., 2014). For this study, the BEEP framework would be adapted to assess the impact investing sector within the selected cases on a national level. Nevertheless, to further understand the environment and design policies for impact investment, examination at sub-national levels is recommended.

\section{The Impact Investing Ecosystem Framework}

Considering that the impact investing sector is different from traditional entrepreneurship, this research combined and adapted the two above mentioned frameworks. Thus, a new framework was established - the Impact Investment Ecosystem Framework, as shown in Figure 3. It is based on the six domains categorized by the BEEP ecosystem framework: policy, markets, human capital, culture, supports, and finance (Isenberg \& Onyemah, 2016). The determinants of the OECD's Social Impact Investment Framework have been reorganized into these six domains. Some of the aspects considered in BEEP, but not in the OECD's Social Impact Investment Framework, have been added to complement the domains of this new framework. The environment variable in the market domain has been added by the authors to acknowledge the fact that impact investment can create environmental value as well. The aspect of networks has been allocated to the supports domain rather than the market domain considering their essential role in supporting the industry and building capacity.

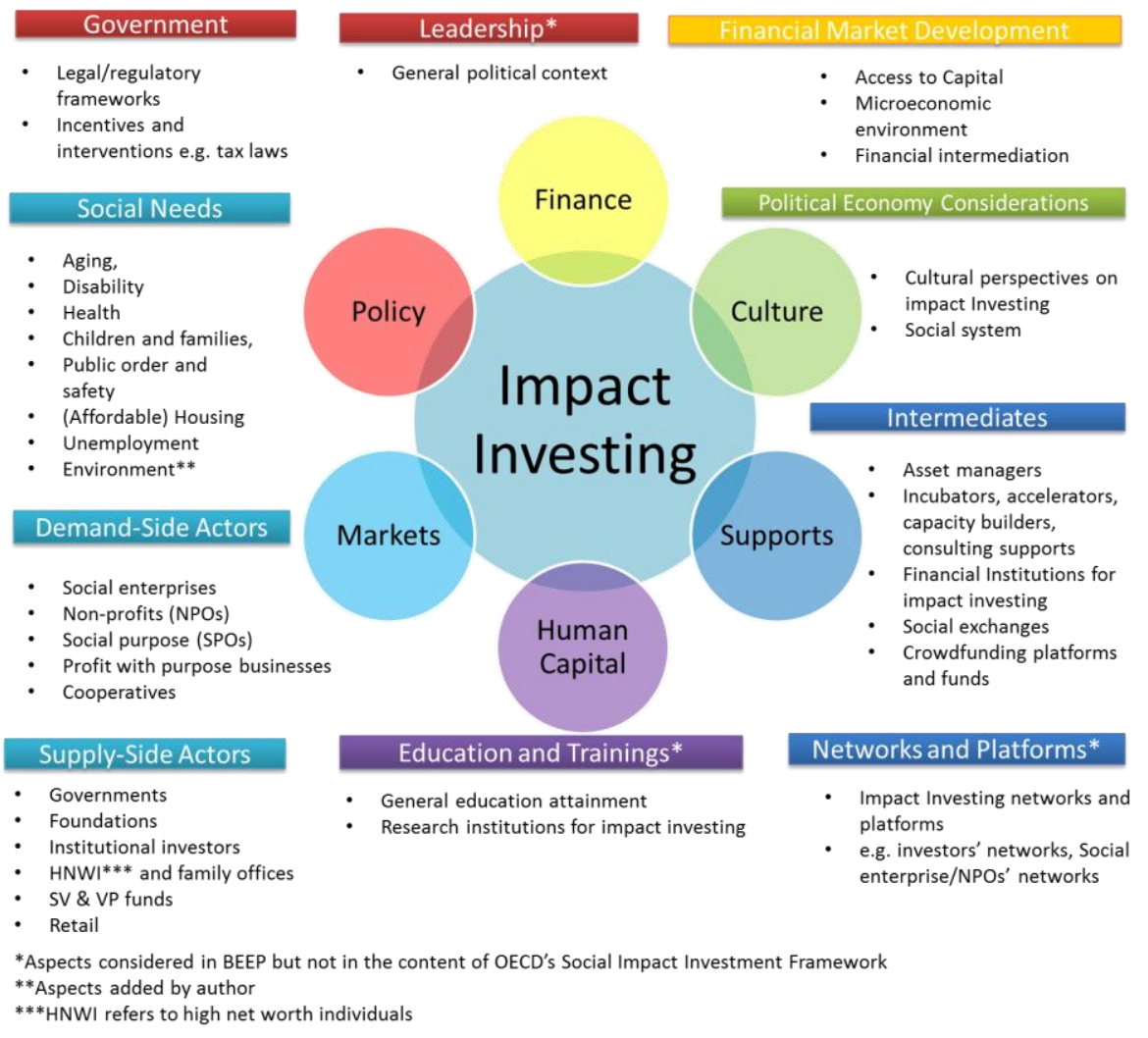

Figure 3. Impact Investing Ecosystem Framework

Source: Authors, adapted from Wilson et al., 2015 and Isenberg \& Onyemah, 2016

\section{Methodology}

The proposed impact investing ecosystem framework was applied in a case study approach to obtain empirical insight into the development of impact investing in Asia. Japan and Singapore were selected as cases. While impact investing is still nascent in Asia, the two chosen countries have relatively active impact investing markets compared to other Asian countries. Japan is a member of the G8 (now G7) Social Impact Investment Taskforce to catalyze the development of impact investing across the globe (SIITF, 2017), while Singapore is the home of important impact investing networks in

2 For example, cities with a population of less than 2 million (see Isenberg \& Onyemah, 2016 for cases). 
Asia, such as the Asian Venture Philanthropy Network (AVPN) and Impact Investment Exchange Asia (IIX).

The benchmark for this research is the highly developed impact investing market in the UK, which is currently the largest across the globe. Furthermore, with the British government's support, various research studies and practices were conducted over the years. Consequently, the UK provides the most data on the development of impact investing (Wilson et al., 2015) and serves as a suitable reference point to make cross-country comparisons.

To assess the six domains of the proposed impact investing ecosystem framework, a set of indicators was selected. This research used secondary data from well-established cross-country development indicators and official governmental information to assure data credibility. Additional information from key impact investing networks in Asia, such as the AVPN, was utilized as a proxy to estimate the market size and identify key players.

The policy domain of the framework examines the political context influencing the impact investing ecosystem in two aspects: leadership and government. The leadership determinant concerns the general political context that enables impact investing. It was assessed through the World Governance Indicators (WGI) by the World Bank (2016), such as political stability, government effectiveness and regulatory quality. The government determinant refers to legislation and governmental interventions. It was evaluated through the existence or absence of an appropriate legal framework (legal forms for social enterprises in particular), the key initiatives, laws, and policies that the government has developed in relation to impact investing. This data was collected through governmental publications and the reports published under the Social Impact Investment Taskforce.

The determinants assessed in the markets domain are demand (social needs), market demand-side actors, and supply-side actors. A set of indicators was selected to measure social needs, including the Social Progress Index (the variables of which are health and wellness, personal safety, shelter, water and sanitation, environmental quality, and maternal and child mortality rates) (Social Progress Imperative, 2017), the World Bank indicators (population ages 65 and above, unemployment rate) (2017a; 2017b), OECD's (2017b) GINI Coefficient for income inequality, and the United Nations Development Program (UNDP)'s (2016) Human Development Index (Gender Inequality Index). The demand-side actors of the market were measured through the number and size of the actors, according to the country-specific forms of related organizations and governmental data. The supply-side actors of the market were assessed through the number of investments made by these actors to address social needs. The indicators include the government's social expenditure (OECD, 2017a; Singapore Government, 2017), the budget of charities and NPOs (Cabinet Office, Japan 2016; Commissioner of Charities [COC], Singapore Government, 2015; Government of UK, 2017a), total donations to charities (Japan Fundraising Association [JFRA], 2015; COC, Singapore Government, 2015; National Council for Voluntary Organisations [NCVO], 2017), total sustainable investment assets (Eurosif, 2016; Global Sustainable Investment Alliance [GSIA], 2016), the size of the impact investment market (Big Society Capital, 2015; Japan National Advisory Board [Japan NAB], 2016) and the total wealth of high network individuals (HNWIs) (Capgemini, 2016). Additionally, examples of impact investors were collected.

The human capital domain, particularly education and training, were assessed through the education index shown in the human development index (HDI) by the UNDP (2016), the years of tertiary schooling according to the Social Progress Index (Social Progress Imperative, 2017) and the Program for International Student Assessment (PISA) by the OECD (2015). Furthermore, several research institutions with a focus on impact investing were examined based on desk research, utilizing information collected by the AVPN (Mohan, Harsh, Modi, \& Gupta, 2017) and the institutions' official websites. Nevertheless, it was difficult to ascertain whether an institution does research on impact investing.

The culture domain analyzes political economy considerations, including cultural perspectives and the social system. The cultural perspectives on impact investing were assessed using the World Giving Index (Charities Aid Foundation [CAF], 2016) as a proxy for citizen attitudes and willingness to engage in solving social problems. The social systems, in this research defined as the political and economic structure of the society, were examined based on Acemoglu and Robinson's (2013) research on the influences of "inclusive" or "extractive" political economic structures.

The supports domain uses a set of relevant organizations to analyze the intermediaries, networks and platforms of impact investing in each country and provides a list of examples.

The finance domain examines the general financial development. The development was assessed through the World Bank Development Indicators (central government finance: debts) (2017c), the World Economic Forum's Inclusive Development Index (financial intermediation of real economy investment) (2017), and the World Competitiveness Index (macroeconomic environment, financial market development, and market size) (2016). All indicators are listed in the table annexed to this paper.

The limitation of this methodology is related to the difficult access to measurable and comparable data for Japan, Singapore and the UK. Since the impact investing industry is at an early stage of development in Asia, there is often 
insufficient information available.

\section{Results and Discussion}

The Policy Domain

Leadership: General political context. Understanding the governments' role in the impact investing ecosystem is essential for creating a positive environment. Generally speaking, the political environments for impact investing in Japan, Singapore, and the UK are enabling. All countries gain positive governance scores in all six WGI indicators by the World Bank (2016), except for Singapore. Although Singapore has a -0.1 score $(-2.5$ to +2.5$)$ in voice and accountability, it has nearly perfect scores in the other five indicators, which still implies an enabling political environment for governance and implementing interventions (World Bank, 2016). As for Japan, its regulatory quality $(+1.2)$ and rule of law (+1.5) are slightly lower than those of Singapore $(+2.3$ and +1.9$)$ and the UK $(+1.9$ and +1.8$)$ (World Bank, 2016). Therefore, it might face more regulatory barriers when developing impact investing. For the UK, the score in political stability and absence of violence is significantly lower $(+0.6)$ than the scores for Japan $(+1.0)$ and Singapore (+1.2) (World Bank, 2016); this could increase uncertainty in the development of impact investing if the political interest changes.

Government: Regulatory frameworks for social enterprises. The existence of enabling regulatory frameworks for social enterprises can directly increase investment opportunities for impact investors. Currently, the legal status of social enterprises is still complex and without a precise definition in the three countries. There has been more progress in the UK. While social enterprises can appear in many forms, a specific form, the community interest company (CIC), was established in 2004 for businesses that benefit the community (Government of UK, 2017b; UK National Advisory Board [UK NAB], 2014). In Singapore, social enterprises come in various entities including for-profit and non-profit (The Law Society of Singapore, 2016). However, the government-funded Singapore Centre for Social Enterprise (raiSE) has provided a status for social enterprises with memberships (raiSE, 2017). For Japan, there is no specific legal entity for social enterprises either (Japan NAB, 2014). The closest effort is the report conducted by the cabinet office to define social enterprises and estimate the market scale (Cabinet Office, Government of Japan, 2015). To help create more impact investments, the three countries, especially Japan, should further consider a specific legal framework for social enterprises.

Government: Interventions and incentives for impact investing. The policy interest in impact investing is evident for all three countries. The UK government is the most active, with a wide range of initiatives, regulations, and policies to support the development of impact investing, including encouraging investors, improving financial environments for social organizations, engaging public actors, building market capacity and infrastructure and creating social impact bonds (see annex). In Japan, two key policies were developed under the initiative of the Social Impact Investment Taskforce, based on the experiences in the UK. Firstly, the government passed a law to enable the use of capital from dormant bank accounts for impact investing purposes. The implementation of this policy is expected by 2019 and applies to the dormant capital since the end of 2016. The approach is similar to the UK's Big Society Capital (The Japan Times, 2016). Secondly, three pilot projects of social impact bonds were launched in 2015, focusing on family care, aging support, and youth employment (Japan NAB, 2016; The Nippon Foundation, 2015). These developments in Japan are considered an encouraging progress for impact investing. In Singapore, there are policies which imply an indirect, not yet specific political interest in the impact investing market, such as providing attractive tax incentives for donations, supporting social enterprises and the social sector (see annex).

In summary, for further development of the impact investing market, the two Asian countries should pursue a comprehensive plan with various types of policies like in the UK.

\section{The Markets Domain}

Demand: Social needs. If social problems are present, there is the opportunity for impact investing in developing a new approach to solving them. Compared with Japan and Singapore, the UK seems to have a greater need to handle social problems in most of the selected areas of this research. However, there is a demand for impact investing in all three countries, although with different focuses and levels of priority.

Regarding the aging of the population, there is a high demand for social projects in all three countries. The Japanese society faces the most serious problem of aging: $26 \%$ of the population in Japan was above 65 years old in 2015 (World Bank, 2017a). While this figure is lower for the UK and Singapore (18\% and 12\% respectively), it is still higher than the world average (8.3\%) and therefore raises concerns (World Bank, 2017a). For disability and health issues, assessed through the Social Progress Index's Health and Wellness indicators, the three countries gain similar scores, although Japan presents the lowest (79.89 out of 100). The performance of the three countries is acceptable, but there is still a demand for healthcare programs (Social Progress Imperative, 2017).

There is a greater demand to improve the welfare of children and families in Singapore and the UK. Singapore presents a 
higher maternal mortality rate (9.98 deaths per 100,000 live births), while the figures for the UK (9.11) and Japan (5.43) are considerably lower (Social Progress Imperative, 2017). For child mortality, the UK has a higher rate (4.2), while Japan and Singapore have the same rate (2.7 deaths per 1,000 live births) (Social Progress Imperative, 2017). In addition, all three countries face the problem of income inequality as they all present figures higher than the OECD average (OECD, 2017a; OECD, 2017b; Department of Statistics Singapore, 2016). Regarding gender, Singapore has a remarkably low gender inequality ${ }^{3}(0.068)$, but the figures for Japan and the UK are also low ( 0.116 and 0.131 respectively), showing few differences between men and women (UNDP, 2016).

For public order and safety, all three countries earn high scores in the Social Progress Index: Singapore scored 93.90 out of 100, the score for Japan is 91.66, and that for the UK is 85.45 (Social Progress Imperative, 2017). However, there is still room for improvement, especially in the UK. For house ownership, Japan and Singapore obtain the similar good scores in the indicator of shelter in the Social Progress Index, at 93.25 and 94.28 out of 100, respectively (Social Progress Imperative, 2017). The UK has a lower score of 87.53 , due to a much more serious problem of affordable housing compared with Japan and Singapore (Social Progress Imperative, 2017). Concerning the job market, the three countries have lower unemployment rates than the world average. The UK has the highest unemployment rate among the three at $4.8 \%$ of the total labor force; for Japan, it is 3.1\%, and for Singapore, it is only 1.8\% (World Bank, 2017b).

For the environment aspect, the set of indicators for environmental quality according to the Social Progress Index was examined. Japan has the lowest total score at 83.82 and the highest greenhouse gas emissions (Social Progress Imperative, 2017). In contrast, outdoor air pollution-attributable deaths are significantly higher in Singapore than in the UK and Japan (Social Progress Imperative, 2017). Furthermore, Singapore's biodiversity and habitat protection is weaker. While the UK shows positive results for most of the indicators of environmental quality, the greenhouse gas emissions are much higher than in Singapore. The environmental conditions in the three countries are generally acceptable. Yet, there is the demand to improve different aspects.

Demand-side actors. The set of country-specific relevant demand-side actors for the three countries is annexed. The presence of these organizations implies the potential demand for impact investments. As the types of actors are different in the three countries, this research only compares the numbers for three similar forms - NPOs/charities, social enterprises, and cooperatives/cooperative societies - by adjusting the numbers according to the population. Compared with Japan and Singapore (both with around 4 per 10,000 inhabitants), the UK has extremely large numbers of NPOs/charities (25 per 10,000 inhabitants). The UK also has the most social enterprises (114 per 10,000 inhabitants). The results show that the UK has a much more active social sector, which provides higher supply and potential for impact investing. A weaker social sector can be more challenging for impact investing growth, as the society is more likely to rely on a traditional approach (the government) to address social issues, which is especially the case for Japan. However, the Japanese and Singaporean government can still apply impact investing, especially with social impact bonds, where the government is actively involved while reducing governmental burdens.

Supply-side actors. The amount of social spending can indicate the government's willingness to address social issues and their potential source of supply. In addition, it can indirectly justify the need for cross-sector collaboration to optimize the use of these resources. Except for Singapore, the levels of governmental social expenditure are high. The governments of Japan and the UK spend over 20\% of their GDP on social issues (OECD, 2017a). Singapore, on the other hand, spends only $8.2 \%$ of its GDP on social development (Singapore Government, 2017). This indicates that the potential supply for impact investment from the government is more than twice as high in the UK and Japan as in Singapore.

The supply for impact investing can also be estimated through the budget of charities and total donations to charities. The charities in Singapore have the highest average budget at USD 4.7 million per year (COC, Singapore Government, 2015), while for the UK it is USD 0.56 million per year (Government of UK, 2017a) and for Japan it is USD 0.43 million per year (Cabinet Office, Government of Japan, 2016). In terms of percent of the national GDP, charities in Singapore receive higher donations than in the UK and Japan (COC, Singapore Government, 2015; JFRA, 2015; NCVO, 2017). This implies that the potential supply for impact investing is higher for Singapore or the UK. Another finding regards the source of donations, namely from individuals or the corporate/private sector. In Japan ${ }^{4}$, corporate donations are about the same amount as individual donations, while in the UK, corporate donations represent only a small part of the total donations (JFRA, 2015; NCVO, 2017). This additional information is important for developing impact investing because it indicates cultural differences.

As another potential supply for impact investing, Japan holds the most HNWI wealth among the three countries at USD

3 The scores of the index: 0 equals to complete equality and 1 equals to complete inequality.

4 For Singapore, there is no comparable data on the sources of donations. However, there are available data for individual donations (NVPC, 2016) and sources of donations of above one million dollars (Coutts, 2015). 
6.57 trillion, while the figures for the UK and Singapore are lower at USD 2.02 trillion and USD 527.1 billion respectively, according to Capgemini's Global Wealth Report (2016).

Regarding the number of actual impact investments, the UK has the largest supply. The Global Sustainable Investment Alliance (GSIA) reflects that the UK currently holds the most sustainable investment assets (7.61\% of global assets), whereas Japan has $2.07 \%$ and Singapore only $0.02 \%$ (GSIA, 2016; Eurosif, 2016). While this calculation has adopted a broader definition for sustainable investment (GISA, 2016), additional information about the market size with a narrower definition of impact investing is available for Japan and the UK. The UK's impact investment value was worth USD 1.92 billion in 2015 (Big Society Capital, 2016), and Japan presented a much smaller market share of USD 0.30 billion (Japan $\mathrm{NAB}, 2016)$. These two indicators show that the current impact investing industry in the UK is much more developed compared with Japan and Singapore. However, there are opportunities for the markets in Japan and Singapore to grow, especially when considering the high HNWI wealth in Japan and the larger amount of donations (\% GDP) to charities in Singapore.

A list of selected impact investors in Japan, Singapore and the UK is annexed. The governments of all three countries have started to participate in the impact investing market, such as the Japan Finance Corporation (JFC) in Japan, raiSE in Singapore, and Big Society Capital in the UK. Compared with Japan, Singapore has more international impact investors, such as the LGT Impact Ventures (IV), LeapFrog Investments, and Bamboo Finance.

\section{The Human Capital Domain}

General education attainment. The development of impact investing as an innovative approach to address social needs will benefit from better education and human resources, as these factors facilitate innovation (Mariz-Pérez, Teijeiro-Álvarez, \& García-Álvarez, 2012). The Education Index from UNDP's Human Development Index measures the average length of education in a country (UNDP, 2016). The three countries all have high scores. The figure for Japan is 0.842 (on a scale between 0 and 1; 1 being the highest); for Singapore, it is 0.814 and for the UK it is 0.896 (UNDP, 2016). While the figure for Singapore is slightly lower, the country instead presents the highest result concerning tertiary education. According to the Social Progress Index, the duration of tertiary schooling is 1.73 years in Singapore, 1.37 years in Japan and only 0.96 years in the UK (Social Progress Imperative, 2017). To evaluate the quality of education, this study used the OECD's (2015) PISA assessment which targets 15-year-old students in different countries and measures their performance in science, mathematics, and reading. Students in Singapore and Japan present significantly high achievements in all three subjects, while the performance of UK students is about average for an OECD country (OECD, 2015). In addition, only 4.8\% of students in Singapore have low performances in all three subjects compared with $5.6 \%$ in Japan (OECD, 2015). In the UK, $10.1 \%$ are low performers in all subjects; this is not much better than other OECD countries (13.0\%) (OECD, 2015).

Singapore and Japan present considerably better results in the above indicators, while all three countries have well-developed human capital to a certain extent. The quality and quantity of human resources in Singapore and Japan are highly advanced, compared with the UK and other countries. This provides a positive environment for impact investing. The valuable human capital in Japan and Singapore enables the creation of social innovations. This is especially the case for Singapore, where the performances are outstanding.

Research institutions for impact investing. Whether there is research interest in impact investing in a country can influence the degree of development, since accessible knowledge is essential for innovative ideas. This research highlighted a few examples as a proxy for the environment of impact investing research. Impact investing is a new field with unclear boundaries; therefore, this research included NPOs and philanthropy, social impact, social enterprises, social innovation, and social finance. The AVPN's latest report on the landscape of impact investing in Asia identified the key relevant research institutions in 16 Asian regions (Mohan et al., 2017). Most of the identified research institutions in Singapore are universities, while Japan has more non-profit associations and foundations (Mohan et al., 2017). In the UK, based on online keyword research, several research institutions exist (see annex). A few research institutions in these three countries have begun to focus on impact investing. It is particularly worth mentioning the establishment of the Social Investment Research Council (SIRC) which consists of five founding members (Big Lottery Fund, Big Society Capital, the Cabinet Office, Citi, and the City of London) and coordinates impact investing research efforts in the interest of key market actors (Big Society Capital, 2015). This is a significant development for impact investing research. However, the field would benefit from further academic engagement. The governments of Japan and Singapore could follow the example of the SIRC initiative in the UK and encourage a research collaboration.

\section{The Culture Domain}

Culture perspectives on impact investing. Cultural perspectives examine to what extent civil society is willing to engage in addressing social challenges. The World Giving Index provides insights into the attitudes of citizens with regard to helping a stranger, donating money, and volunteering (CAF, 2016). This could be a proxy for understanding the cultural 
differences regarding impact investing. Among the three countries, the UK obtains the highest rank for philanthropic activities, ranking in the top eight in the world (CAF, 2016). Singapore is ranked 28th; the participation in these activities is approximately $10 \%$ lower (CAF, 2016). Clearly behind the UK and Singapore, Japan is ranked 114th in the world; only $24 \%$ of the citizens in the survey participate in philanthropic activities and the score is $30 \%$ lower than that of the UK (CAF, 2016).

These very different figures demonstrate how the culture of giving differs in the three societies. The UK has a very active social sector that can contribute to solving social problems and further lead to the development of social innovations. The culture of giving is also promising in Singapore, which represents an enabling factor that supports the growth of impact investing. The culture of giving in Japan, on the other hand, seems weak. This could be a key challenge for developing impact investing there.

Social system. The design of social systems, meaning the general political and economic structures, influences the impact investing ecosystem. Acemoglu and Robinson (2013) have indicated that a nation's development depends on whether their political economic institutions are inclusive of society or extractive for the benefits of a few elites. Inclusive institutions are more likely to promote entrepreneurships and innovations (Acemoglu \& Robinson, 2013). Likewise, this can enable social innovations and social entrepreneurship, further supporting the development of impact investing. Based on this theory and the analysis of the World Economic Forum's Global Competitiveness Index (2016), the economic institutions in research are all qualified as inclusive. The three countries are ranked in the top 10 in the world (World Economic Forum, 2016). To assess the political institutions, the World Bank's (2016) WGI indicators were applied as standards. Japan and the UK's political institutions are more inclusive as they gain positive scores in all WGI indicators. Singapore's political institutions are rather extractive, earning negative scores for voice and accountability. Japan and the UK, where the economic and political institutions are all inclusive, are more likely to enable the development of impact investing. However, Singapore's political economic environment is a special case. While its political power is not well distributed, the government is especially efficient. Moreover, the economic environment is remarkably enabling. As a result, the development of impact investing in Singapore is not limited, though it might be more challenging politically.

\section{The Supports Domain}

Intermediaries. Intermediaries are important support for the impact investing ecosystem, as they help to develop market infrastructures, build capacity, and improve market efficiency. The focus of this research is to determine whether certain intermediation exists between the supply and demand and to identify examples. A list of examples ${ }^{5}$ for intermediaries is presented in four categories (see annex). Through this list, this research has collected evidence that intermediaries are currently building the capacity of impact investing in the UK, Japan, and Singapore, with the participation of public, private, and social sectors together. The set of intermediaries is different for the three countries, but organizations with similar functions usually exist. In Japan, there seem to be fewer public actors involved in market intermediation. In the UK, the most important examples of governmental actors include Big Society Capital, CDC which provides tailored overseas investment support (CDC Group, 2017) and a pilot P2P Impact Fund established in 2015 which supports social enterprises in accessing crowdfunding platforms (Cabinet Office, Government of UK, 2015). In Singapore, the National Council of Social Service, raiSE, and Tote Board are quasi-governmental organizations that provide support to social enterprises and the social sector. The philanthropic crowdfunding platform "Giving.sg." has also been established by the government. In addition, the presence of the social stock exchange platforms in Singapore and the UK gives the two countries a higher level of intermediation than Japan.

Platforms and networks. The existence of networks and platforms is essential for impact investing as they provide information and knowledge that can improve communication and build capacity. A list of networks and platforms, though not exhaustive, is provided in the annex. The three countries have access to platforms with similar functions, from global-level networks to regional or local ones. The AVPN report has identified the key networks and platforms for Singapore and Japan (Mohan et al., 2017). There are fifteen organizations listed in Singapore, but only seven in Japan. From this aspect, it seems that Singapore has more access to impact investing networks and platforms. This result suggests that the Japanese government could consider putting more effort into building infrastructure support for the impact investment market, while it is evident that the intermediaries, networks and platforms are developing in all three countries.

\section{The Finance Domain}

Governments in debt. The government's financial condition can show whether the governmental resources are sufficient

The intermediaries in Japan and Singapore are identified by the AVPN report (Mohan et al., 2017). Additionally, based on keyword research and the information on existing networks, such as the Social Investment Forum (UK) and the Global Impact Investment Network, examples for the three countries are given. 
to address the growing social needs. The World Development Indicators provide information about the revenue and expenses of the governments, as well as the amount of their debt (World Bank, 2017c). It is observed that all three governments are in debt. This reflects why impact investing is needed in the first place - new solutions are essential for society especially given a lack of traditional resources. The Japanese government has the highest debt (198\% GDP) among the three countries (World Bank, 2017c). In the UK and Singapore, the governmental debts are lower at 107.6\% GDP and 107.2\% GDP, yet still higher than the average of high-income countries (101.1\%) (World Bank, 2017c). In addition, the governments of the UK and Japan struggle to balance their budgets with deficits. Singapore, on the other hand, keeps a revenue of 2.2\% GDP (World Bank, 2017c).. In general, there is a demand for impact investing in all three countries because they all face insufficient governmental resources. Especially the UK and Japan could profit from engaging private capital as part of the development of impact investing.

Financial market development. A well-developed financial market is more likely to support the development of impact investing. Singapore and Japan have enabling financial conditions in general for impact investing growth similar to the UK. With regard to economic development in general, the World Competitiveness Index has shown that all three countries are more advanced than the rest of the world (World Economic Forum, 2016). Notably, Singapore is ranked in the top two in the index, while the UK is in the top seven and Japan in the top eight (World Economic Forum, 2016). For financial market development, in particular, Singapore is ranked second as well, while the UK (16th) and Japan (17th) are at about the same level (World Economic Forum, 2016). However, Japan and the UK have advantages in market size (ranked fourth, and ninth) in contrast to Singapore's relatively small market (ranked 37th) (World Economic Forum, 2016). Compared with other economies in the world, the three countries have relatively efficient, trustworthy, and confident market and financial systems. The conditions in the two Asian countries create an enabling environment for impact investing. The smaller market size in Singapore does not limit the development of impact investing.

Financial intermediation for inclusive growth. In addition to the general financial market development, this research further examined the aspect of inclusive economic growth through the "financial intermediation of real economy investment" pillar by the World Economic Forum's (2017) new Inclusive Development Index. An inclusive economy enables impact investing to grow. The results show that the three countries all have medium-high financial foundations and environments for inclusive growth. Singapore, with the highest score of 5.50 (from lowest 1 to highest 7) among the three countries, performs in the top $20 \%$ among advanced economies (World Economic Forum, 2017). The UK obtained a score of 4.77 (top 40\%), and Japan a score of 4.53 (World Economic Forum, 2017). The financial system inclusion in Singapore has room to improve, especially when compared with the UK. Namely, it can increase the affordability of accessing capital and financial services in the country. The financial intermediation in Japan is also relatively weak compared with Singapore, the UK, and other advanced countries. Therefore, the efficiency of intermediation from assets to investment opportunities needs to be improved to encourage the development of impact investing.

\section{Conclusions and Policy Recommendations}

The proposed impact investing ecosystem framework has provided a comprehensive overview of the actors in the impact investing market and has identified its key challenges and possibilities. The merge and adaptation of the OECD social impact investment framework and the entrepreneurial ecosystem approach have proven as an effective method since it complements the analytical approaches of the two frameworks and allows cross-country comparisons. In this case study, the proposed impact investing ecosystem framework has found overall enabling environments in Japan and Singapore for the development of impact investing, although different challenges exist. While the market demand is relatively small compared with the UK due to fewer apparent social needs, the two Asian countries have similar political economic systems, high-quality human resources and well-developed financial markets. As Japan faces heavy debt and social expenditures and Singapore has a limited budget for social development, impact investing is beneficial for both countries as a new solution to supplement governmental resources. Essential intermediaries and networks are already developing in both countries to support the market. Consequently, impact investing has great potential to grow in Japan and Singapore. To maximize this potential, public policy plays an important role. Firstly, it is essential that the governments understand how they can influence every determinant of the impact investing ecosystem, e.g. the legal frameworks and existing policies. By supporting enabling factors in all the different domains of this ecosystem, the government can catalyze its development. As the benchmark of the UK shows, public policy can build market capacity, increase demand, encourage investors, and provide capital or shape the social systems to invest private capital in social services.

Japan. Japan is a country with high governmental social spending. Since it has the highest debt among the three countries and cannot balance its budget, the government should seek alternative resources to help solve the growing social issues. Therefore, the demand for impact investing is high. The government has the following suggestions to promote impact investing in Japan. Firstly, when compared to the other two countries, the key challenges are aging, income inequality, unemployment, and the environment (especially greenhouse gas emissions). The government can first examine the current structures of social services in these areas and then provide incentives for impact investments. Secondly, as the 
Japanese society has a relatively weak social sector, the government should put more efforts into building market capacity and catalyzing private capital. For example, it can become more involved in supporting intermediaries, investing in relevant research, or providing training programs. Additionally, given Japan's unique donation structure, the government can provide tax incentives for the corporate sector to invest in SPOs. The government can also focus on mobilizing the HNWIs in the country because they offer a rich source for impact investing. Thirdly, a legal framework for social enterprises is needed. The regulatory quality and rule of law in general are relative weaknesses of the Japanese governance compared with the other two countries. A clear framework will allow the government to create tailored tax incentives and attract impact investors. Lastly, the Japanese government should consider the proposals of the Japan Impact Investment Taskforce which provides a comprehensive plan for the development of impact investing in Japan. These proposals, based on the successful experiences of the UK government, can also help to overcome the challenge of a weaker social sector.

Singapore. Singapore has the highest quality and quantity of human resources, the most advanced financial market, and a government that ranks higher on good governance rankings compared to the other two countries. Furthermore, it has more access to international impact investors as well as international and regional impact investing networks than Japan. As a result, the impact investing industry in Singapore is promising. Impact investments can serve as a great additional resource for solving social problems given the fact that the government has a limited budget. Based on the analysis of this research, the key social challenges are aging, welfare for children and families, income inequality and environmental issues (especially outdoor air pollution, biodiversity, and habitat protection). The government can take all domains of the ecosystem into consideration to enable impact investing and design new interventions that address these problems. Singapore can take advantage of the access to international networks and financial markets to engage impact investors. Additionally, the government can establish a research institution to gain and provide essential knowledge in the field. Lastly, the government can consider introducing social impact bonds to promote impact investing. The implementation of pilot social impact bonds can demonstrate the benefit to society and the cost-effectiveness for the government which would allow Singapore to maintain its low social spending strategy. Given the effectiveness and trustworthiness of the Singaporean government, there is a great potential for these projects to succeed.

\section{References}

Acemoglu, D., \& Robinson, J. A. (2013). Why nations fail: The origins of power, prosperity, and poverty. Crown Business.

Achleitner, A. K., Heinecke, A., Noble, A., Schöning, M., \& Spiess-Knafl, W. (2011). Unlocking the Mystery: An Introduction to Social Investment. Innovations, 6(3), 145-154.

Ács, Z. J., Autio, E., \& Szerb, L. (2014). National Systems of Entrepreneurship: Measurement Issues and Policy Implications. Research Policy, 43(3), 476-494.

Adner, R. (2017). Ecosystem as Structure: An Actionable Construct for Strategy. Journal of Management, 43(1), 39-58. https://doi.org/10.1177/0149206316678451

Asian Development Bank. (2011). Impact investors in Asia: characteristics and preferences for investing in social enterprises in Asia and the Pacific. Asian Development Bank. Retrieved from https://www.adb.org/publications/impact-investors-asia-characteristics-and-preferences-investing-social-enterprise s-asia

Autio, E., Kenney, M., Mustar, P., Siegel, D., \& Wright, M. (2014). Entrepreneurial Innovation: The Importance of Context. Research Policy, 43(7), 1097-1108. https://doi.org/10.1016/j.respol.2014.01.015

Big Society Capital. (2015, November 27). Research council. Retrieved June 24, 2017, from http://www.bigsocietycapital.com/what-we-do/current-projects/research-council

Big Society Capital. (2016). The size and composition of social investment in the UK. Retrieved from https://www.bigsocietycapital.com/latest/type/research/size-and-composition-social-investment-uk

Borzaga, C., \& Defourny, J. (2001). From third sector to social enterprise. London: Routledge.

Borzaga, C., \& Defourny, J. (2004). The emergence of social enterprise (Vol. 4). Psychology Press.

Bugg-Levine, A., \& Emerson, J. (2011). Impact Investing: Transforming How We Make Money While Making a Difference. Innovations, 6(3), 9-18.

Bugg-Levine, A., \& Goldstein, J. (2009). Impact investing: Harnessing Capital Markets to Solve Problems at Scale. Community Development Investment Review, (2), 30-41.

Cabinet Office, Government of Japan. (2015). A report on the aggregated activity size of social enterprises in Japan. 
Retrieved from https://www.google.de/url?sa=t\&rct=j\&q=\&esrc=s\&source=web\&cd=1\&cad=rja\&uact=8\&ved=0ahUKEwi5yYL OsMzUAhWHuhQKHRKdB6AQFggoMAA\&url=https\%3A\%2F\%2Fwww.npo-homepage.go.jp\%2Fuploads\%2F kigyou-chousa-summary.pdf\&usg=AFQjCNH7nFevKdJOpTK-0JHtnQeYUCchTA\&sig2=bWilQAPTJagAQwRBI dlWjA

Cabinet Office, Government of Japan. (2016). Actual condition survey on social contribution of Specified Nonprofit Corporation and citizens in 2015 (平成 27 年度 特定非営利活動法人及び市民の社会貢献に関する実態調查). Retrieved from https://www.npo-homepage.go.jp/uploads/h27_houjin_shimin_chousa_all.pdf

Cabinet Office, Government of Japan. (2017). NPO. Retrieved June 16, 2017, from https://www.npo-homepage.go.jp/

Cabinet Office, Government of UK. (2015). P2P Impact Fund: social enterprises get $£ 2$ million boost - GOV.UK. Retrieved June 26, 2017, from https://www.gov.uk/government/news/p2p-impact-fund-social-enterprises-get-2-million-boost

Cabinet Office, Government of UK. (2016). Social enterprise: market trends 2014 - GOV.UK. Retrieved June 20, 2017, from https://www.gov.uk/government/publications/social-enterprise-market-trends-2014

Capgemini. (2016). Global wealth report 2016. Retrieved from https://www.worldwealthreport.com/download

CDC Group. (2017). Home | CDC Group. Retrieved June 25, 2017, from http://www.cdcgroup.com/

Charities Aid Foundation [CAF]. (2016). CAF World Giving Index 2016: The world's leading study of generosity. Charities Aid Foundation (CAF).

Charity Poptal, Singapore Government. (2017). About charities and IPCs. Retrieved June 20, 2017, from https://www.charities.gov.sg/setting-up-a-charity/Pages/About-Charities-And-IPCs.aspx

Clark, C., Emerson, J., \& Thornley, B. (2014). The impact investor: Lessons in leadership and strategy for collaborative capitalism. John Wiley \& Sons.

Cohen, B. (2006). Sustainable Valley Entrepreneurial Ecosystems. Business Strategy and the Environment, 15(1), 1-14.

Commissioner of Charities [COC], Singapore Government. (2015). Commissioner of Charities (COC) Annual report 2015. Retrieved from https://www.charities.gov.sg/Publications/Pages/Publications.aspx

Community Chest. (2017). SHAREasOne. Retrieved June 26, 2017, from http://www.comchest.org.sg/comchest/SHAREasOne/tabid/1186/Default.aspx

Coutts. (2015). Million Dollar Donor Reports. Retrieved from http://philanthropy.coutts.com/en/reports/2015/singapore/findings.html

Dacin, M. T., Dacin, P. A., \& Tracey, P. (2011). Social Entrepreneurship: A Critique and Future Directions. Organization Science, 22(5), 1203-1213. https://doi.org/10.1287/orsc.1100.0620

Department of Statistics Singapore. (2016). Key household income trends, 2016. Retrieved from https://www.singstat.gov.sg/docs/default-source/default-document-library/publications/publications_and_papers/ho usehold_income_and_expenditure/pp-s23.pdf

Emerson, J. (2003). The Blended Value Proposition: Integrating Social and Financial Returns. California Management Review, 45(4), 35-51. https://doi.org/10.2307/41166187

European Commission. (2011). Proposal for a regulation of the European Parliament and of the Council on a European Union programme for social change and innovation. Retrieved March 21, 2017, from http://eur-lex.europa.eu/legal-content/EN/TXT/PDF/?uri=CELEX:52011PC0609\&from=EN

Eurosif. (2016). European SRI study 2016. Retrieved from https://www.eurosif.org/sri-study-2016/

Ferdinand, J. P., \& Meyer, U. (2017). The Social Dynamics of Heterogeneous Innovation Ecosystems: Effects of Openness on Community-firm Relations. International Journal of Engineering Business Management, 9, 1847979017721617. https://doi.org/10.1177/1847979017721617

Financial Conduct Authority. (2017). Mutuals public register. Retrieved June 20, 2017, from https://mutuals.fsa.gov.uk/Search.aspx

Fraiberg, S. (2017). Start-Up Nation: Studying Transnational Entrepreneurial Practices in Israel's Start-Up Ecosystem. Journal of Business and Technical Communication, 31(3), 350-388. https://doi.org/10.1177/1050651917695541

Global Sustainable Investment Alliance [GSIA]. (2016). 2016 Global sustainable investment review.

Government of UK. (2016). Social investment: a force for social change 2016 strategy. Retrieved from 
https://www.gov.uk/government/uploads/system/uploads/attachment_data/file/507215/6.1804_SIFT_Strategy_260 216_FINAL_web.pdf

Government of UK. (2017a). Recent charity register statistics: Charity Commission. Retrieved June 20, 2017, from https://www.gov.uk/government/publications/charity-register-statistics/recent-charity-register-statistics-charity-co mmission

Government of UK. (2017b). Setting up a social enterprise - GOV.UK. Retrieved June 26, 2017, from https://www.gov.uk/set-up-a-social-enterprise

Harji, K., \& Jackson, E. T. (2012). Accelerating impact: Achievements, challenges and what's next in building the Impact Investing Industry.

Herman, R. P. (2010). The HIP investor: Make bigger profits by building a better world. John Wiley \& Sons.

Höchstädter, A. K., \& Scheck, B. (2015). What's in a Name: An Analysis of Impact Investing Understandings by Academics and Practitioners. Journal of Business Ethics, 132(2), 449-475. https://doi.org/10.1007/s10551-014-2327-0

Isenberg, D. (2016). Applying the Ecosystem Metaphor to Entrepreneurship: Uses and Abuses. The Antitrust Bulletin, 61(4), 564-573. https://doi.org/10.1177/0003603X16676162

Isenberg, D., \& Onyemah, V. (2016). Fostering Scaleup Ecosystems for Regional Economic Growth (Innovations Case Narrative: Manizales-Mas and Scale Up Milwaukee). Innovations, 11(1-2), 60-79.

Jackson, E. T. (2013). Interrogating the Theory of Change: Evaluating Impact Investing Where It Matters Most. Journal of Sustainable Finance \& Investment, 3(2), 95-110. https://doi.org/10.1080/20430795.2013.776257

Japan Fundraising Association [JFRA]. (2015). Giving Japan 2015. Retrieved from http://jfra.jp/wp/wp-content/themes/jfra2015/img/english/pdf/givingjapan2015.pdf

Japan National Advisory Board [Japan NAB]. (2014). The social impact investment landscape in Japan. G8 Social Impact Investment Taskforce.

Japan National Advisory Board [Japan NAB]. (2016). Current state of social impact investment in Japan 2016. Retrieved from http://impactinvestment.jp/2016/09/sii.html

Louche, C., Arenas, D., \& Cranenburgh, K. C. van. (2012). From Preaching to Investing: Attitudes of Religious Organisations Towards Responsible Investment. Journal of Business Ethics, 110(3), 301-320. https://doi.org/10.1007/s10551-011-1155-8

Mariz-Pérez, R. M., Teijeiro-Álvarez, M. M., \& García-Álvarez, M. T. (2012). The Importance of Human Capital in Innovation: A System of Indicators. In Soft Computing in Management and Business Economics (pp. 31-44). Springer, Berlin, Heidelberg. https://doi.org/10.1007/978-3-642-30451-4_3

Mason, C., \& Brown, R. (2014). Entrepreneurial ecosystems and growth oriented entrepreneurship. Final Report to OECD, Paris, 1-38.

Mendell, M., \& Barbosa, E. (2013). Impact Investing: a Preliminary Analysis of Emergent Primary and Secondary Exchange Platforms. Journal of Sustainable Finance \& Investment, 3(2), 111-123. https://doi.org/10.1080/20430795.2013.776258

Ministry of Culture, Community and Youth [MCCY], Singapore Government. (2014a). MCCY - Institutions of a Public Character (IPCs). Retrieved June 26, 2017, from

https://www.mccy.gov.sg/en/Topics/Charities/Articles/Institutions_of_a_Public_Character.aspx

Ministry of Culture, Community and Youth [MCCY], Singapore Government. (2014b). VWOs-Charities Capability Fund (VCF). Retrieved June 20, from https://www.mccy.gov.sg/en/Topics/Charities/Articles/VCF.aspx

Ministry of Culture, Community and Youth [MCCY], Singapore Government. (2017a). Co-operative Societies. Retrieved August 4, 2017, from https://www.mccy.gov.sg/en/Topics/Charities/Articles/Cooperative_Societies.aspx

Ministry of Culture, Community and Youth [MCCY], Singapore Government. (2017b). Mutual Benefit Organisations. Retrieved August 4, 2017, from https://www.mccy.gov.sg/en/Topics/Charities/Articles/Mutual_Benefit_Organisations.aspx

Ministry of Culture, Community and Youth [MCCY], Singapore Government. (2017c). VWOs-Charities Capability Fund (VCF). Retrieved June 20, from https://www.mccy.gov.sg/en/Topics/Charities/Articles/Central_Co-operative_Fund.aspx 
Mohan, A., Harsh, S., Modi, A., \& Gupta, A. (2017). Social investment landscape in Asia. AVPN.

Moore, M. L., Westley, F. R., \& Nicholls, A. (2012a). The Social Finance and Social Innovation Nexus. Journal of Social Entrepreneurship, 3(2), 115-132. https://doi.org/10.1080/19420676.2012.725824

Moore, M. L., Westley, F. R., Tjornbo, O., \& Holroyd, C. (2012b). The Loop, the Lens, and the Lesson: Using Resilience Theory to Examine Public Policy and Social Innovation. In Alex Nicholls \& A. Murdock (Eds.), Social Innovation (pp. 89-113). London: Palgrave Macmillan UK. https://doi.org/10.1057/9780230367098_4

National Council for Voluntary Organisations [NCVO]. (2017). UK Civil Society Almanac 2017 / Income data. Retrieved June 20, 2017, from https://data.ncvo.org.uk/a/almanac17/income-data/

National Council of Social Service [NCSS], Singapore Government. (2017). List of NCSS Members. Retrieved June 20, 2017, from https://www.ncss.gov.sg/GatewayPages/Voluntary-Welfare-Organisations/Membership/List-of-NCSS-Members

National Volunteer \& Philanthropy Centre [NVPC]. (2016). Individual giving survey. Retrieved from https://www.nvpc.org.sg/individual-giving-survey

Neck, H. M., Meyer, G. D., Cohen, B., \& Corbett, A. C. (2004). An Entrepreneurial System View of New Venture Creation. Journal of Small Business Management, 42(2), 190-208.

Nicholls, A. (2010). The Institutionalization of Social Investment: The Interplay of Investment Logics and Investor Rationalities. Journal of Social Entrepreneurship, 1(1), 70-100. https://doi.org/10.1080/19420671003701257

Nicholls, A., \& Opal, C. (2005). Fair Trade: Market-Driven Ethical Consumption. SAGE Publications. Retrieved from https://books.google.de/books?id=ZzN63m4tEi4C

Ormiston, J., Charlton, K., Donald, M. S., \& Seymour, R. G. (2015). Overcoming the Challenges of Impact Investing: Insights from Leading Investors. Journal of Social Entrepreneurship, 6(3), 352-378. https://doi.org/10.1080/19420676.2015.1049285

Park, J., \& Choi, M. (2014). A Cross-National Study on Mobile Business: How Will Ecosystems Evolve? Information Development, 30(1), 9-21. https://doi.org/10.1177/0266666912465975

Pilinkienè, V., \& Mačiulis, P. (2014). Comparison of Different Ecosystem Analogies: The Main Economic Determinants and Levels of Impact. Procedia - Social and Behavioral Sciences, 156, 365-370. https://doi.org/10.1016/j.sbspro.2014.11.204

Public Interest Commission, Cabinet Office, Government of Japan. (2014). Promoting public interest activities by the private sector. Retrieved from https://www.koeki-info.go.jp/pictis_portal/contents.do?bunNo=1120733660\&meisaiNo=1120832782

Rangan, V. K., Appleby, S., \& Moon, L. (2011). The Promise of Impact Investing. Harvard Business School, Background Note, (512-045).

Seelos, C., \& Mair, J. (2005). Social Entrepreneurship: Creating New Business Models to Serve the Poor. Business Horizons, 48(3), 241-246. https://doi.org/10.1016/j.bushor.2004.11.006

Singapore Centre for Social Enterprise [raiSE]. (2017). Retrieved June 20, 2017, from https://www.raise.sg/

Singapore Government. (2017). Analysis of revenue and expenditure: Financial year 2017. Retrieved from http://www.singaporebudget.gov.sg/data/budget_2017/download/FY2017_Analysis_of_Revenue_and_Expenditure .pdf

Social Finance UK. (2017). Impact bond database. Retrieved August 13, 2017, from http://www.socialfinance.org.uk/database/

Social Impact Investment Taskforce [SIITF]. (2014). Impact investment: The invisible heart of markets. OECD. Available at: http://www. socialimpactinvestment. org/reports/Impact\% 20Investment\% 20Report\% 20FINAL [3]. pdf [Accessed 2 October 2016]. Retrieved from http://www.ietp.com/sites/default/files/Impact\%20Investment\%20Report\%20FINAL.pdf

Social Impact Investment Taskforce [SIITF]. (2017). Global social impact investment steering group. Retrieved July 1, 2017, from http://socialimpactinvestment.org/

Social Investment Forum. (2017) Members. Retrieved from http://www.socialinvestmentforum.org.uk/members

Social Progress Imperative. (2017). Social Progress Index 2017. Retrieved August 11, 2017, from http://www.socialprogressimperative.org/ 
Stam, E. (2015). Entrepreneurial Ecosystems and Regional Policy: A Sympathetic Critique. European Planning Studies, 23(9), 1759-1769. https://doi.org/10.1080/09654313.2015.1061484

Sunley, P., \& Pinch, S. (2012). Financing Social Enterprise: Social Bricolage or Evolutionary Entrepreneurialism? Social Enterprise Journal, 8(2), 108-122. https://doi.org/10.1108/17508611211252837

The Japan Times. (2016, December 2). Diet passes bill to allow use of dormant deposits for public interest. The Japan Times Online. Retrieved from http://www.japantimes.co.jp/news/2016/12/02/business/diet-passes-bill-allow-use-dormant-deposits-public-interest l

The Law Society of Singapore. (2016). Legalese: a legal handbook for community organizations. Retrieved from http://probono.lawsociety.org.sg/Documents/LEGALESE_Second\%20Edition\%20(web).pdf

The Nippon Foundation. (2015). Progress report on Japan's first 3 pilot projects. Retrieved June 26, 2017, from http://www.nippon-foundation.or.jp/en/news/articles/2015/134.html

The Organization for Economic Co-operation and Development [OECD]. (2015). Program for International Student Assessment (PISA). Retrieved April 7, 2017, from http://www.oecd.org/pisa/

The Organization for Economic Co-operation and Development [OECD]. (2017a). OECD Statistics. Retrieved June 11, 2017, from http://stats.oecd.org/

The Organization for Economic Co-operation and Development [OECD]. (2017b) Inequality. Retrieved June 11, 2017, from http://www.oecd.org/social/inequality.htm

UK National Advisory Board [UK NAB]. (2014). Building a social impact investment market- The UK experience. Retrieved June 20, 2017, from

http://www.socialimpactinvestment.org/reports/UK\%20Advisory\%20Board\%20to\%20the\%20Social\%20Investme nt\%20Taskforce\%20Report\%20September\%202014.pdf

United Nations Development Program [UNDP] (Ed.). (2016). Human development for everyone. New York, NY: United Nations Development Program.

Volkmann, C., Tokarski, K., \& Ernst, K. (2012). Social entrepreneurship and social business. An introduction and discussion with case studies. Gabler. Wiesbaden.

Wilson, K. E., Silva, F., \& Ricardson, D. (2015). Social Impact Investment: Building the Evidence Base. Retrieved from https://papers.ssrn.com/sol3/papers.cfm?abstract_id=2562082

Wood, D., \& Hagerman, L. (2010). Mission Investing and the Philanthropic Toolbox. Policy and Society, 29(3), 257-268. https://doi.org/10.1016/j.polsoc.2010.07.005

Wood, D., Thornley, B., \& Grace, K. (2013). Institutional Impact Investing: Practice and Policy. Journal of Sustainable Finance \& Investment, 3(2), 75-94. https://doi.org/10.1080/20430795.2013.776256

World Bank. (2016). Worldwide governance indicators. Retrieved April 14, 2017, from http://info.worldbank.org/governance/wgi/index.aspx\#reports

World Bank. (2017a). Population ages 65 and above (\% of total) | Data. Retrieved June 11, 2017, from http://data.worldbank.org/indicator/SP.POP.65UP.TO.ZS

World Bank. (2017b). Unemployment, total (\% of total labor force) (modeled ILO estimate) | Data. Retrieved June 11, 2017, from http://data.worldbank.org/indicator/SL.UEM.TOTL.ZS?view=chart

World Bank. (2017c). World development indicators: Central government finances. Retrieved August 11, 2017, from http://databank.worldbank.org/data/reports.aspx?source=2\&series=GC.REV.XGRT.GD.ZS,GC.XPN.TOTL.GD.ZS ,GC.NFN.TOTL.GD.ZS,GC.NLD.TOTL.GD.ZS,GC.AST.TOTL.GD.ZS,GC.LBL.TOTL.GD.ZS,GC.DOD.TOTL. GD.ZS,GC.XPN.INTP.RV.ZS\#

World Bank. (2017d). World development indicators - GDP (current US\$). Retrieved August 11, 2017, from http://databank.worldbank.org/data/reports.aspx? source=2\&series=NY.GDP.MKTP.CD\&country=

World Bank. (2017e). World development indicators - Population, total. Retrieved August 11, 2017, from http://databank.worldbank.org/data/reports.aspx?source=2\&series=SP.POP.TOTL\&country=\#

World Economic Forum. (2016). The global competitiveness report 2016-2017. Retrieved from http://reports.weforum.org/global-competitiveness-index/

World Economic Forum. (2017). The inclusive growth and development report 2017. 


\begin{tabular}{|c|c|c|c|c|c|c|}
\hline $\begin{array}{c}\text { Actors/Factor } \\
\mathrm{s}\end{array}$ & \begin{tabular}{|c|} 
Data \\
Sources and \\
Dates
\end{tabular} & Indicators & Unit & Japan & Singapore & UK \\
\hline \multicolumn{7}{|l|}{ Domain: Policy } \\
\hline \multicolumn{7}{|l|}{ Leadership } \\
\hline \multirow{6}{*}{$\begin{array}{l}\text { General } \\
\text { political } \\
\text { context }\end{array}$} & \multirow{6}{*}{$\begin{array}{c}\text { Worldwide } \\
\text { governance } \\
\text { indicators } \\
\text { (WGI) } 2015 \\
\text { (World Bank, } \\
2016)\end{array}$} & $\begin{array}{c}\text { Voice and } \\
\text { Accountability }\end{array}$ & $\begin{array}{l}\text { Governance } \\
\text { score }(-2.5 \text { to } \\
+2.5)\end{array}$ & 1.0 [79.3] & -0.1 [42.9] & 1.3 [92.1] \\
\hline & & $\begin{array}{c}\text { Political } \\
\text { Stability and } \\
\text { Absence of } \\
\text { Violence }\end{array}$ & \multirow{5}{*}{$\begin{array}{l}\text { [Percentile } \\
\text { Rank (low: } 0 \\
\text { to high: 100)] }\end{array}$} & $1.0[82.4]$ & $1.2[93.3]$ & $0.6[62.4]$ \\
\hline & & $\begin{array}{c}\text { Government } \\
\text { Effectiveness }\end{array}$ & & 1.8 [95.7] & $2.3[100.0]$ & 1.7 [93.8] \\
\hline & & $\begin{array}{c}\text { Regulatory } \\
\text { Quality }\end{array}$ & & $1.2[85.1]$ & $2.3[100.0]$ & 1.9 [98.6] \\
\hline & & Rule of Law & & $1.5[89.4]$ & $1.9[96.6]$ & $1.8[93.8]$ \\
\hline & & $\begin{array}{l}\text { Control of } \\
\text { corruption }\end{array}$ & & 1.6 [91.3] & $2.1[97.1]$ & 1.9 [94.2] \\
\hline \multicolumn{7}{|l|}{ Government } \\
\hline \multirow[b]{2}{*}{$\begin{array}{l}\text { Legal/regulato } \\
\text { ry frameworks }\end{array}$} & \multirow{2}{*}{$\begin{array}{c}\text { Government } \\
\text { of UK, } \\
\text { 2017b; UK } \\
\text { NAB, 2014;; } \\
\text { raiSE, 2017; } \\
\text { Japan NAB, } \\
\text { 2014; } \\
\text { Cabinet } \\
\text { Office, } \\
\text { Government } \\
\text { of Japan, } \\
\text { 2015 } \\
\end{array}$} & \multirow[b]{2}{*}{$\begin{array}{l}\text { The existence or } \\
\text { absence of legal } \\
\text { frameworks for } \\
\text { social } \\
\text { enterprises }\end{array}$} & \multirow[b]{2}{*}{-- } & $\begin{array}{c}\text { No specific legal } \\
\text { status }\end{array}$ & $\begin{array}{l}\text { No specific } \\
\text { legal status }\end{array}$ & $\begin{array}{c}\text { Not limited to } \\
\text { one specific } \\
\text { legal status } \\
\end{array}$ \\
\hline & & & & $\begin{array}{l}\text { Regulated by the } \\
\text { Cabinet Office }\end{array}$ & $\begin{array}{l}\text { Certification: } \\
\text { raiSE } \\
\text { membership }\end{array}$ & $\begin{array}{c}\text { Specific } \\
\text { form: CIC }\end{array}$ \\
\hline \multirow{5}{*}{$\begin{array}{l}\text { Interventions } \\
\text { and incentives } \\
\text { e.g. tax laws }\end{array}$} & \multirow{5}{*}{$\begin{array}{c}\text { Japan NAB, } \\
\text { 2014; Japan } \\
\text { NAB, 2016; } \\
\text { The Japan } \\
\text { Times, 2016; } \\
\text { The Nippon } \\
\text { Foundation, } \\
\text { 2015; UK } \\
\text { NAB, 2014; } \\
\text { Government } \\
\text { of UK, 2016; } \\
\text { raiSE, 2017; } \\
\text { Singapore } \\
\text { Government } \\
\text { (MCCY, } \\
\text { 2014a, } \\
\text { 2014b, } \\
\text { 2017c); } \\
\text { Community } \\
\text { Chest, 2017; } \\
\text { AVPN } \\
\text { (Mohan et }\end{array}$} & $\begin{array}{l}\text { Key initiatives, } \\
\text { laws, policies, } \\
\text { and actions } \\
\text { created for } \\
\text { impact } \\
\text { investing: }\end{array}$ & -- & -- & -- & -- \\
\hline & & \multirow[b]{2}{*}{$\begin{array}{l}\text { Initiatives to } \\
\text { support the } \\
\text { development of } \\
\text { impact investing }\end{array}$} & \multirow[b]{2}{*}{-- } & \multirow[b]{2}{*}{$\begin{array}{c}\text {-The G8 Social } \\
\text { Impact Investment } \\
\text { Taskforce }\end{array}$} & - raiSE (2015) & $\begin{array}{c}\text { - Social Value } \\
\text { Act }\end{array}$ \\
\hline & & & & & $\begin{array}{c}\text { - National } \\
\text { Volunteer and } \\
\text { Philanthropy } \\
\text { Centre } \\
\text { (NVPC) }\end{array}$ & $\begin{array}{c}\text { - The G8 } \\
\text { Social Impact } \\
\text { Investment } \\
\text { Taskforce }\end{array}$ \\
\hline & & \multirow{2}{*}{$\begin{array}{l}\text { Tax incentives } \\
\text { for non-profits } \\
\text { and social } \\
\text { enterprises }\end{array}$} & \multirow[t]{2}{*}{-- } & $\begin{array}{c}\text { Furusato Tax } \\
\text { (Hometown Tax) } \\
\text { System }\end{array}$ & \multirow{2}{*}{$\begin{array}{c}\text { Tax } \\
\text { incentives for } \\
\text { Institutions of } \\
\text { Public } \\
\text { Character } \\
\text { (IPCs) }\end{array}$} & $\begin{array}{c}\text { Community } \\
\text { Investment } \\
\text { Tax Relief } \\
\text { (CITR) } \\
\end{array}$ \\
\hline & & & & $\begin{array}{l}\text { Tax incentives for } \\
\text { public-interest } \\
\text { corporations, } \\
\text { certified non-profit }\end{array}$ & & $\begin{array}{c}\text { Social } \\
\text { Investment } \\
\text { Tax Relief }\end{array}$ \\
\hline
\end{tabular}




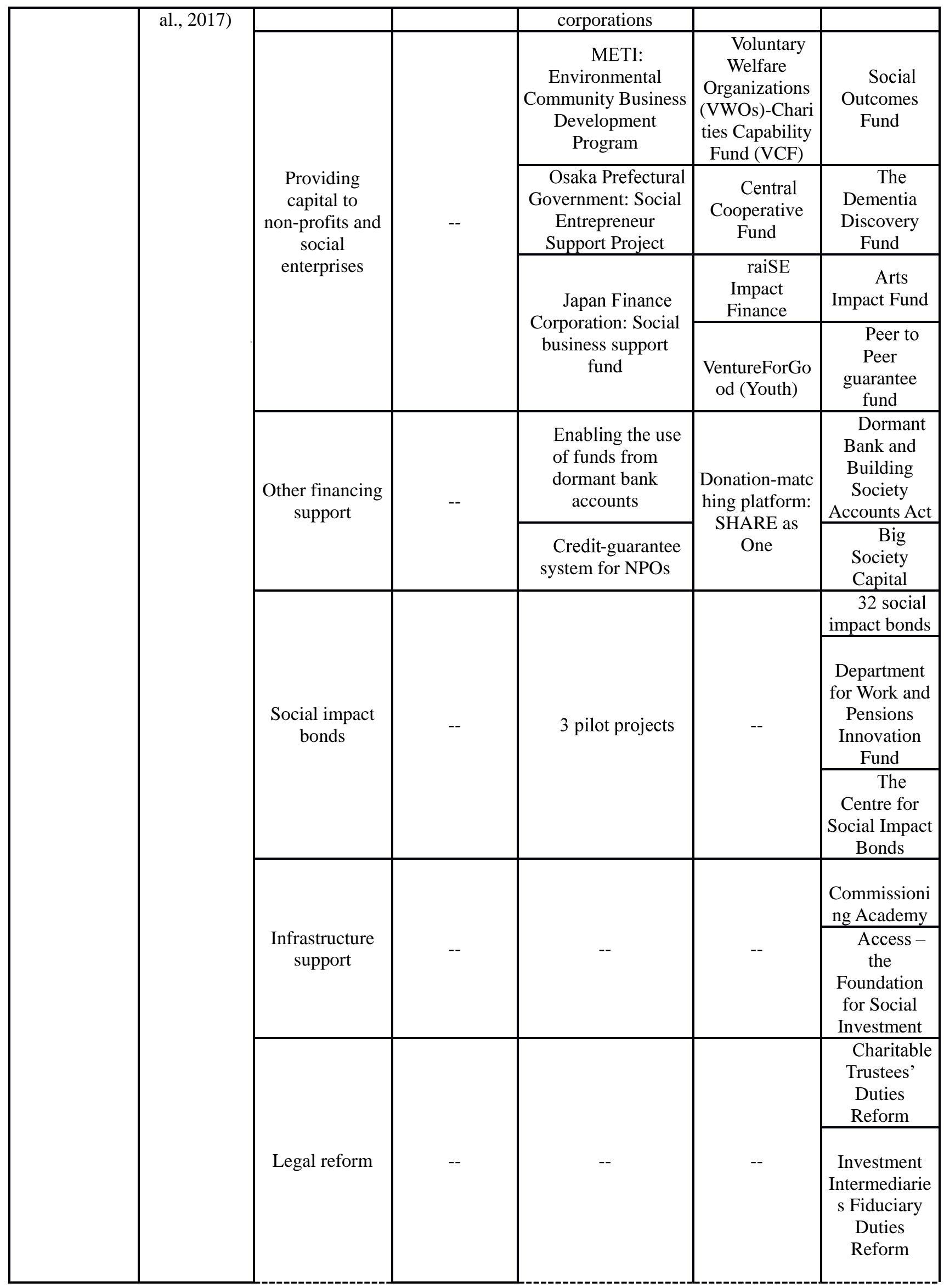




\begin{tabular}{|c|c|c|c|c|c|c|}
\hline \multicolumn{7}{|c|}{\begin{tabular}{|l|} 
Domain: Markets \\
\end{tabular}} \\
\hline \multicolumn{7}{|c|}{ Demand: Social Needs } \\
\hline Aging & $\begin{array}{c}\text { World Bank } \\
\text { estimates } \\
2015 \text { (World } \\
\text { Bank, 2017a) } \\
\end{array}$ & $\begin{array}{l}\text { Population aged } \\
65 \text { and above }\end{array}$ & $\begin{array}{l}\% \text { of total } \\
\text { [World } \\
\text { average] }\end{array}$ & $26[8.3]$ & $12[8.3]$ & $18[8.3]$ \\
\hline $\begin{array}{l}\text { Disability } \\
\text { Health }\end{array}$ & $\begin{array}{c}\text { Social } \\
\text { Progress } \\
\text { Index 2017 } \\
\text { (Social } \\
\text { Progress } \\
\text { Imperative,2 } \\
017 \text { ) }\end{array}$ & $\begin{array}{l}\text { Health and } \\
\text { wellness } \\
\text { (based on: Life } \\
\text { expectancy at } \\
60, \text { premature } \\
\text { deaths from } \\
\text { non-communica } \\
\text { ble diseases, } \\
\text { suicide rate) }\end{array}$ & $\begin{array}{l}\text { Calculated } \\
\text { Score (low: } 0 \\
\text { to high: 100) }\end{array}$ & 79.89 & 83.78 & 81.16 \\
\hline \multirow{4}{*}{$\begin{array}{l}\text { Children and } \\
\text { families }\end{array}$} & \multirow{2}{*}{$\begin{array}{c}\text { Social } \\
\text { Progress } \\
\text { Index 2017 } \\
\text { (Social } \\
\text { Progress } \\
\text { Imperative, } 2 \\
017 \text { ) }\end{array}$} & $\begin{array}{c}\text { Maternal } \\
\text { mortality rate }\end{array}$ & $\begin{array}{c}\text { Deaths/100,00 } \\
0 \text { live births }\end{array}$ & 5.43 & 9.98 & 9.11 \\
\hline & & $\begin{array}{l}\text { Child mortality } \\
\text { rate }\end{array}$ & $\begin{array}{c}\text { Deaths } / 1,000 \\
\text { live births }\end{array}$ & 2.70 & 2.70 & 4.20 \\
\hline & $\begin{array}{c}\text { OECD, } \\
2017 \mathrm{a} ; \\
2017 \mathrm{~b} \\
\text { Department } \\
\text { of Statistics, } \\
\text { Singapore, } \\
2016 \\
\end{array}$ & $\begin{array}{c}\text { GINI } \\
\text { Coefficient } \\
\text { (household; } \\
\text { disposable } \\
\text { income, post } \\
\text { taxes and } \\
\text { transfers) } \\
\end{array}$ & \begin{tabular}{|c|}
0 to 1 (date of \\
data) [OECD \\
average 2014] \\
(complete \\
equality: $0 ;$ \\
complete \\
inequality: 1 ) \\
\end{tabular} & $0.33[0.318](2012)$ & $\begin{array}{c}0.402[0.318] \\
\quad(2016)\end{array}$ & $\begin{array}{c}0.358 \text { [0.318] } \\
\quad(2013)\end{array}$ \\
\hline & $\begin{array}{c}\text { Human } \\
\text { Development } \\
\text { Index (HDI) } \\
2015 \\
\text { (UNDP, } \\
2016) \\
\end{array}$ & $\begin{array}{c}\text { Gender } \\
\text { Inequality Index }\end{array}$ & $\begin{array}{c}0 \text { to } 1 \\
\text { (complete } \\
\text { equality: } 0 \\
\text { complete } \\
\text { inequality: } 1 \text { ) }\end{array}$ & 0.116 & 0.068 & 0.131 \\
\hline $\begin{array}{l}\text { Public order } \\
\text { and safety }\end{array}$ & $\begin{array}{c}\text { Social } \\
\text { Progress } \\
\text { Index 2017 } \\
\text { (Social } \\
\text { Progress } \\
\text { Imperative, } 2 \\
017 \text { ) }\end{array}$ & $\begin{array}{l}\text { Personal Safety } \\
\text { (based on: } \\
\text { Homicide rate, } \\
\text { level of violent } \\
\text { crime, perceived } \\
\text { criminality, } \\
\text { political terror, } \\
\text { traffic deaths) }\end{array}$ & $\begin{array}{c}\text { Calculated } \\
\text { Score (low: } 0 \\
\text { to high: 100) }\end{array}$ & 91.66 & 93.90 & 85.45 \\
\hline \multirow{5}{*}{$\begin{array}{l}\text { (Affordable) } \\
\text { Housing }\end{array}$} & \multirow{5}{*}{$\begin{array}{c}\text { Social } \\
\text { Progress } \\
\text { Index } 2017 \\
\text { (Social } \\
\text { Progress } \\
\text { Imperative,2 } \\
017 \text { ) }\end{array}$} & $\begin{array}{l}\text { Shelter based } \\
\text { on: }\end{array}$ & \begin{tabular}{|c|} 
Calculated \\
Score (low: 0 \\
to high: 100 ) \\
\end{tabular} & 93.25 & 94.28 & 87.53 \\
\hline & & $\begin{array}{c}\text { Availability of } \\
\text { affordable } \\
\text { housing }\end{array}$ & $\%$ satisfied & 76 & 75 & 44 \\
\hline & & $\begin{array}{l}\text { Access to } \\
\text { electricity }\end{array}$ & $\begin{array}{c}\% \text { of } \\
\text { population }\end{array}$ & 100.00 & 100.00 & 100.00 \\
\hline & & $\begin{array}{l}\text { Quality of } \\
\text { electricity } \\
\text { supply }\end{array}$ & $\begin{array}{l}\text { Scale (low: } 1 \\
\text { to high: } 7 \text { ) }\end{array}$ & 6.55 & 6.81 & 6.67 \\
\hline & & $\begin{array}{c}\text { Household air } \\
\text { pollution-attribu }\end{array}$ & $\begin{array}{c}\text { deaths } / 100,00 \\
0\end{array}$ & 0.00 & 0.00 & 0.00 \\
\hline
\end{tabular}




\begin{tabular}{|c|c|c|c|c|c|c|}
\hline & & table deaths & & & & \\
\hline $\begin{array}{c}\text { Unemploymen } \\
\mathrm{t}\end{array}$ & \begin{tabular}{|c|} 
World Bank \\
2016 \\
(modeled \\
ILO \\
estimate) \\
(2017b) \\
\end{tabular} & $\begin{array}{l}\text { Unemployment } \\
\text { rate }\end{array}$ & $\begin{array}{l}\% \text { of total } \\
\text { labor force } \\
\text { [world } \\
\text { average] }\end{array}$ & $3.1[5.7]$ & $1.8[5.7]$ & $4.8[5.7]$ \\
\hline \multirow{6}{*}{ Environment } & \multirow{6}{*}{\begin{tabular}{|c|} 
Social \\
Progress \\
Index 2017 \\
(Social \\
Progress \\
Imperative, 2 \\
017 )
\end{tabular}} & 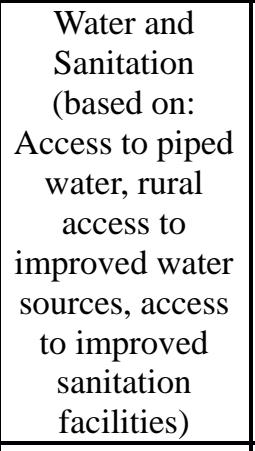 & $\begin{array}{l}\text { Calculated } \\
\text { Score (low: } 0 \\
\text { to high: } 100 \text { ) }\end{array}$ & 99.58 & 100.00 & 99.74 \\
\hline & & \begin{tabular}{|c|} 
Environmental \\
Quality based \\
on: \\
\end{tabular} & \begin{tabular}{|l|} 
Calculated \\
Score (low: 0 \\
to high: 100$)$ \\
\end{tabular} & 83.82 & 87.11 & 91.88 \\
\hline & & $\begin{array}{c}\text { Outdoor air } \\
\text { pollution-attribu } \\
\text { table deaths }\end{array}$ & $\begin{array}{c}\text { deaths/100,00 } \\
0\end{array}$ & 16.83 & 32.45 & 22.80 \\
\hline & & $\begin{array}{c}\text { Wastewater } \\
\text { treatment }\end{array}$ & $\begin{array}{c}\% \text { of } \\
\text { wastewater }\end{array}$ & 56.53 & 100.00 & 96.34 \\
\hline & & $\begin{array}{c}\text { Biodiversity and } \\
\text { habitat }\end{array}$ & $\begin{array}{l}\text { Protection } \\
\text { (low: } 0 \text { to } \\
\text { high: } 100 \text { ) } \\
\end{array}$ & 93.25 & 72.26 & 98.98 \\
\hline & & $\begin{array}{c}\text { Greenhouse gas } \\
\text { emissions }\end{array}$ & $\begin{array}{c}\mathrm{CO}_{2} \\
\text { equivalent per } \\
\text { GDP } \\
\end{array}$ & 301.27 & 141.59 & 237.80 \\
\hline \multicolumn{7}{|c|}{ Demand-Side Actors } \\
\hline \multirow{4}{*}{$\begin{array}{c}\text { Social } \\
\text { enterprises } \\
\text { NPOs SPOs } \\
\text { Profit-with-pur } \\
\text { pose } \\
\text { businesses } \\
\text { Cooperatives }\end{array}$} & \multirow{4}{*}{\begin{tabular}{|c|} 
Japan: \\
Cabinet \\
Office: \\
(2017; 2015; \\
Public \\
Interest \\
Commission, \\
2014); Japan \\
NAB, 2014. \\
Singapore: \\
raiSE, 2016; \\
Singapore \\
Government \\
(COC, 2015; \\
Ministry of \\
Culture, \\
\end{tabular}} & \multirow{4}{*}{$\begin{array}{l}\text { Number of } \\
\text { organizations }\end{array}$} & \multirow{4}{*}{$\begin{array}{c}\text { Number [per } \\
1,000,000 \\
\text { population }^{6} \text { ] }\end{array}$} & $\begin{array}{c}\text { NPOs: } 51,508 \\
\text { [405.13] Certified } \\
\text { NPOs }^{7}: 1016 \text { [7.99] }\end{array}$ & $\begin{array}{c}\text { Charities: } \\
2,217[400.54] \\
\text { IPCs }^{8}: 633 \\
{[114.36]} \\
\end{array}$ & $\begin{array}{l}\text { Charities: } \\
167,109 \\
{[2,565.82]}\end{array}$ \\
\hline & & & & $\begin{array}{l}\text { Social enterprises: } \\
205,000 \text { [1612.38] }\end{array}$ & $\begin{array}{c}\text { Social } \\
\text { enterprises': } \\
303 \text { [54.74] }\end{array}$ & $\begin{array}{c}\text { Social } \\
\text { enterprises: } \\
741,000 \\
{[11,377.44]} \\
\end{array}$ \\
\hline & & & & $\begin{array}{c}\text { Cooperatives: } 36,492 \\
{[287.02]}\end{array}$ & $\begin{array}{c}\text { Cooperative } \\
\text { societies: } 85 \\
{[15.36]}\end{array}$ & $\begin{array}{c}\text { Cooperative } \\
\text { and } \\
\text { community } \\
\text { benefit } \\
\text { societies: } \\
8,208 \\
{[126.03]} \\
\end{array}$ \\
\hline & & & & -Social welfare & -Mutual & Community \\
\hline
\end{tabular}

${ }^{6}$ The authors calculated all of these based on the World Bank Development Indicators (population total, 2015) (World Bank, 2017e).

${ }^{7}$ Donations to Certified NPOs are eligible for income tax deduction.

${ }^{8}$ IPCs refer to the exempt or registered charities capable of issuing tax-deductible receipts to donors. Donations to the certified IPCs are tax-deductible (Charity Portal, Singapore Government, 2017).

${ }^{9}$ Number of Social Enterprises with memberships in the raiSE. 


\begin{tabular}{|c|c|c|c|c|c|c|}
\hline & \begin{tabular}{|c} 
Community \\
and Youth \\
[MCCY], \\
$2014 \mathrm{a}$, \\
$2017 \mathrm{a}$, \\
2017b; \\
National \\
Council of \\
Social \\
Service \\
[NCSS], \\
2017) UK: \\
Government \\
of UK \\
(2017a; \\
Cabinet \\
Office, \\
2016); \\
Financial \\
Conduct \\
Authority, \\
2017
\end{tabular} & & & \begin{tabular}{|c} 
organizations: \\
19,000 [149.44] \\
-Education \\
organizations: 8,000 \\
[62.92] \\
-Associations/Found \\
ations: 41,000 \\
[322.48] \\
-Public-interest \\
corporations: 9300 \\
[73.15]
\end{tabular} & $\begin{array}{c}\text { Benefit } \\
\text { Organizations: } \\
84 \text { [15.18]. } \\
\text {-Voluntary } \\
\text { welfare } \\
\text { organizations } \\
\text { (VWOs) }^{10}: \\
473[85.46]\end{array}$ & $\begin{array}{c}\text { interest } \\
\text { companies } \\
(\mathrm{CICs}): \\
11922 \\
{[183.05]}\end{array}$ \\
\hline \multicolumn{7}{|c|}{ Supply-Side Actors } \\
\hline \multirow{4}{*}{$\begin{array}{c}\text { Governments } \\
\text { Foundations } \\
\text { Institutional } \\
\text { investors } \\
\text { HNWI and } \\
\text { family offices } \\
\text { SV \& VP funds } \\
\text { Retail }\end{array}$} & \begin{tabular}{|c} 
OECD \\
Social \\
Expenditure \\
(OECD,2017 \\
a; Singapore: \\
Singapore \\
Government, \\
2017) \\
\end{tabular} & $\begin{array}{l}\text { Social } \\
\text { expenditure } \\
\text { (public) }\end{array}$ & $\begin{array}{c}\% \text { of GDP [\% } \\
\text { of OECD } \\
\text { average] }\end{array}$ & $23.06[21.12](2013)$ & $\begin{array}{l}8.2[21.03] \\
\quad(2016)\end{array}$ & $\begin{array}{l}21.49 \text { [21.03] } \\
\quad(2016)\end{array}$ \\
\hline & $\begin{array}{c}\text { Cabinet } \\
\text { Office, Japan } \\
\text { 2016; COC, } \\
\text { Singapore } \\
\text { Government, } \\
\text { 2015; } \\
\text { Government } \\
\text { of UK, 2017a } \\
\end{array}$ & $\begin{array}{c}\text { Annual charity } \\
\text { budget (Japan: } \\
\text { NPOs) }\end{array}$ & $\begin{array}{c}\text { total USD } \\
{\left[\mathrm{USD}^{11} \text { per }\right.} \\
\text { organization] }\end{array}$ & $\begin{array}{c}22.27 \mathrm{bn}^{12}[432 \mathrm{k}] \\
(2017)\end{array}$ & $\begin{array}{c}10.51 \mathrm{bn} \\
{[4,742 \mathrm{k}]} \\
(2014)\end{array}$ & $\begin{array}{c}93.58 \text { bn }[560 \\
\text { k] } \\
(2014)\end{array}$ \\
\hline & \multirow{2}{*}{$\begin{array}{c}\text { JFRA, 2015; } \\
\text { COC, } \\
\text { Singapore } \\
\text { Government, } \\
2015 ; \\
\text { NCVO, } 2017\end{array}$} & $\begin{array}{l}\text { Total donations } \\
\text { to charity }\end{array}$ & \multirow{2}{*}{$\begin{array}{l}\text { USD [\% of } \\
2014 \mathrm{GDP}^{13} \text { ] }\end{array}$} & 12.96 bn [0.0027] & $\begin{array}{c}1.82 \mathrm{bn} \\
{[0.0059]} \\
(2014) \\
\end{array}$ & $\begin{array}{l}11.14 \mathrm{bn} \\
{[0.0037]}\end{array}$ \\
\hline & & $\begin{array}{l}\text { Individual } \\
\text { donations }\end{array}$ & & $\begin{array}{c}6.67 \text { bn [0.0014] } \\
(2014)\end{array}$ & N/A & $\begin{array}{c}9.79 \mathrm{bn} \\
{[0.0033]} \\
(2014 / 15)\end{array}$ \\
\hline
\end{tabular}

${ }^{10}$ Number of VWOs with membership in the National Council of Social Service (NCSS). VWOs are NPOs (service providers) that benefit the community in Singapore (NCSS, 2017).

${ }^{11}$ The authors estimated all financial values in the table and calculated from local currencies to USD with exchange rates: 1 Euro $=1.12$ USD; 1 British Pound $=1.28$ USD; 1 Japanese Yen $=0.0090$ USD; 1 Singapore Dollar $=0.72$ USD (achieved through Google Finance, 2017/06/19).

${ }^{12}$ Estimated for the current number of NPOs $(51,508)$ from the average annual income of NPOs by Japan's Cabinet Office in 2015 (Cabinet Office, Government of Japan, 2016)

${ }^{13}$ Figures calculated by the authors based on the World Bank Development Indicators (GDP, 2014) (World Bank, 2017d). 


\begin{tabular}{|c|c|c|c|c|c|c|}
\hline & & $\begin{array}{c}\text { Corporate/Priva } \\
\text { te sector } \\
\text { donation }\end{array}$ & & $\begin{array}{c}\text { Corporate: } 6.29 \mathrm{bn} \\
\text { [0.0013] (2014) }\end{array}$ & N/A & $\begin{array}{c}1.35 \mathrm{bn} \\
{[0.0005]} \\
(2014 / 15) \\
\end{array}$ \\
\hline & $\begin{array}{c}\text { Eurosif, } \\
\text { 2016; GSIA, } \\
2016\end{array}$ & $\begin{array}{c}\text { Total } \\
\text { sustainable } \\
\text { investment } \\
\text { assets }^{14} \\
\end{array}$ & $\begin{array}{c}\text { USD [\% of } \\
\text { global assets] }\end{array}$ & 473.6 bn [2.07] & 4.3 bn $[0.02]$ & $\begin{array}{c}1,742.0 \mathrm{bn} \\
{[7.61]}\end{array}$ \\
\hline & $\begin{array}{l}\text { Big Society } \\
\text { Capital, } \\
\text { 2015; Japan } \\
\text { NAB, 2016. }\end{array}$ & $\begin{array}{l}\text { Impact } \\
\text { investment } \\
\text { market size }\end{array}$ & USD & $0.30 \mathrm{bn} \quad$ (2016) & N/A & $\begin{array}{l}1.92 \mathrm{bn} \\
(2015)\end{array}$ \\
\hline & Capgemini: & HNWI Wealth & $\begin{array}{l}\text { USD [\% of } \\
\text { global HNWI } \\
\text { wealth] }\end{array}$ & 6,571.4 bn [11.20] & $\begin{array}{c}527.1 \mathrm{bn} \\
{[0.90]}\end{array}$ & $\begin{array}{c}2,024.0 \mathrm{bn} \\
{[3.45]}\end{array}$ \\
\hline & $\begin{array}{l}\text { Wealth } \\
\text { Report, } 2016\end{array}$ & $\begin{array}{c}\text { HNWI } \\
\text { Population }\end{array}$ & $\begin{array}{l}\text { Population [\% } \\
\text { of country's } \\
\text { total } \\
\left.\text { population }^{15}\right] \\
\end{array}$ & $2,720.0 \mathrm{k}[2.14]$ & $103.6 \mathrm{k}$ [1.87] & $552.8 \mathrm{k}[0.85]$ \\
\hline & & & & $\cdot \mathrm{JFC}$ & $\begin{array}{l}\text { - LGT Impact } \\
\text { Ventures (IV) }\end{array}$ & $\begin{array}{c}\text { - Big Society } \\
\text { Capital }\end{array}$ \\
\hline & & & & $\begin{array}{c}\text { Nippon } \\
\text { Foundation }\end{array}$ & $\begin{array}{l}\text { Bamboo } \\
\text { Finance }\end{array}$ & $\begin{array}{l}\text { Big Issue } \\
\text { Invest }\end{array}$ \\
\hline & & & & $\begin{array}{c}\text { Mitsubishi } \\
\text { Corporation Disaster } \\
\text { Relief Fund } \\
\end{array}$ & $\begin{array}{l}\text { Omidyar } \\
\text { Network }\end{array}$ & \begin{tabular}{|c|} 
Esmee \\
Fairbairn \\
Foundation \\
\end{tabular} \\
\hline & & & & $\begin{array}{l}\text { Music Securities, } \\
\text { Inc. }\end{array}$ & $\begin{array}{c}\text { East } \\
\text { Ventures }\end{array}$ & $\begin{array}{c}\text { Social } \\
\text { Investment } \\
\text { Business } \\
\end{array}$ \\
\hline & $\begin{array}{l}\text { Japan NAB, } \\
\text { 2016; AVPN }\end{array}$ & Examples of & & $\begin{array}{l}\text { Gojo \& Company, } \\
\text { Inc. }\end{array}$ & $\begin{array}{r}\text { LeapFrog } \\
\text { Investments }\end{array}$ & UnLtd \\
\hline & & (e.g. impact & -- & $\begin{array}{c}\text { Fukutake } \\
\text { Foundation }\end{array}$ & raiSE & \begin{tabular}{|c|} 
Big \\
Lottery Fund \\
\end{tabular} \\
\hline & $\begin{array}{l}\text { keyword } \\
\text { research }\end{array}$ & foundations) & & $\begin{array}{r}\text { Inamori } \\
\text { Foundation } \\
\end{array}$ & $\begin{array}{c}\text { DBS } \\
\text { Foundation } \\
\end{array}$ & $\begin{array}{r}\text { LGT } \\
\text { Impact }\end{array}$ \\
\hline & & & & $\begin{array}{c}\text { Benesse } \\
\text { Corporation Toyota } \\
\text { Tsusho } \\
\end{array}$ & & $\begin{array}{c}\text { City } \\
\text { Bridge Trust }\end{array}$ \\
\hline & & & & $\begin{array}{r}\text { Globis Capital } \\
\text { Partners, KIBOW }\end{array}$ & & $\begin{array}{c}\text { Lloyds } \\
\text { Bank } \\
\text { Foundation } \\
\end{array}$ \\
\hline & & & & & & \begin{tabular}{|c|} 
RBS \\
MicroFinanc \\
e Funds \\
(MFF) \\
\end{tabular} \\
\hline Domain: $\mathrm{H}$ & Capital & & & & & \\
\hline Education & ining & & & & & \\
\hline & $\begin{array}{c}\text { Human } \\
\text { Development }\end{array}$ & $\begin{array}{c}\text { Education Index } \\
(0 \text { to } 1)\end{array}$ & $\begin{array}{c}\text { Low: 0, High: } \\
1 \\
\end{array}$ & 0.842 & 0.814 & 0.896 \\
\hline $\begin{array}{l}\text { General } \\
\text { education }\end{array}$ & $\begin{array}{l}\text { Index (HDI) } \\
2015\end{array}$ & $\begin{array}{l}\text { Mean Years of } \\
\text { Schooling }\end{array}$ & Years & 12.5 & 11.6 & 13.3 \\
\hline & $\begin{array}{l}\text { (UNDP, } \\
2016)\end{array}$ & $\begin{array}{c}\text { Expected Years } \\
\text { of Schooling }\end{array}$ & Years & 15.3 & 15.4 & 16.3 \\
\hline
\end{tabular}

${ }^{14}$ The assets that are professionally managed under responsible investment strategies.

${ }^{15}$ Figures calculated by the authors based on the World Bank Development Indicators (Population total, 2015) (World Bank, 2017e). 


\begin{tabular}{|c|c|c|c|c|c|c|}
\hline & $\begin{array}{c}\text { Social } \\
\text { Progress } \\
\text { Index } 2017 \\
\text { (Social } \\
\text { Progress } \\
\text { Imperative, } 2 \\
\text { 017) } \\
\end{array}$ & $\begin{array}{l}\text { Years of tertiary } \\
\text { schooling }\end{array}$ & Years & 1.37 & 1.73 & 0.96 \\
\hline & & $\begin{array}{c}\text { Student } \\
\text { performance in: } \\
\text { Science } \\
\end{array}$ & $\begin{array}{l}\text { mean score } \\
\text { [OECD }\end{array}$ & 538 [493] & 556 [493] & 509 [493] \\
\hline & & Mathematics & $\begin{array}{c}\text { countries } \\
\text { average score] }\end{array}$ & 532 [490] & 564 [490] & 492 [490] \\
\hline & (OECD & Reading & & 516 [493] & 535 [493] & 498 [493] \\
\hline & 2015) & $\begin{array}{l}\text { Low performers } \\
\text { in all subjects: } \\
\text { (math, reading, } \\
\text { and science) }\end{array}$ & $\begin{array}{c}\% \text { [\% OECD } \\
\text { Average] }\end{array}$ & $5.6[13.0]$ & $4.8[13.0]$ & $10.1[13.0]$ \\
\hline & & & & $\begin{array}{l}\text { Fujitsu Research } \\
\text { Institute }\end{array}$ & $\begin{array}{c}\text { Earth } \\
\text { Observatory of } \\
\text { Singapore, } \\
\text { Nanyang } \\
\text { Technological } \\
\text { University }\end{array}$ & $\begin{array}{c}\text { Centre for } \\
\text { Enterprise } \\
\text { and } \\
\text { Economic } \\
\text { Development } \\
\text { Research, } \\
\text { Middlesex } \\
\text { University } \\
\text { London } \\
\end{array}$ \\
\hline & & & & $\begin{array}{l}\text { Japan Foundation } \\
\text { Center }\end{array}$ & $\begin{array}{r}\text { INSEAD } \\
\text { (Singapore) }\end{array}$ & $\begin{array}{c}\text { Institute } \\
\text { for Social } \\
\text { Innovation } \\
\text { and Impact, } \\
\text { University of } \\
\text { Northampton } \\
\end{array}$ \\
\hline Research & AVPN & Fxamples of & & $\begin{array}{l}\text { Japan Fundraising } \\
\text { Association (JFRA) }\end{array}$ & $\begin{array}{l}\text { Lien Centre } \\
\text { for Social } \\
\text { Innovation } \\
\text { (LCSI) } \\
\end{array}$ & iSE \\
\hline $\begin{array}{c}\text { institutions for } \\
\text { impact } \\
\text { investing }\end{array}$ & $\begin{array}{l}\text { (Mohan et } \\
\text { al., 2017); } \\
\text { keyword } \\
\text { research }\end{array}$ & $\begin{array}{l}\text { research } \\
\text { institutions for } \\
\text { impact investing }\end{array}$ & - & Japan NPO Center & $\begin{array}{l}\text { NUS Asia } \\
\text { Centre for } \\
\text { Social } \\
\text { Entrepreneurs } \\
\text { hip and } \\
\text { Philanthropy }\end{array}$ & $\begin{array}{l}\text { Marshall } \\
\text { Institute for } \\
\text { Philanthropy } \\
\text { and Social } \\
\text { Entrepreneur } \\
\text { ship, The } \\
\text { London } \\
\text { School of } \\
\text { Economics } \\
\text { and Political } \\
\text { Science } \\
\end{array}$ \\
\hline & & & & $\begin{array}{r}\text { Nippon } \\
\text { Foundation }\end{array}$ & $\begin{array}{r}\text { Republic } \\
\text { Polytechnic }\end{array}$ & $\begin{array}{c}\text { Oxford } \\
\text { University, } \\
\text { Saïd Business } \\
\text { School } \\
\end{array}$ \\
\hline & & & & $\begin{array}{l}\text { Sasakawa Peace } \\
\text { Foundation }\end{array}$ & $\begin{array}{c}\text { School of } \\
\text { Social } \\
\text { Sciences, } \\
\text { Singapore } \\
\text { Management } \\
\text { University } \\
\end{array}$ & SIRC \\
\hline & & & & & Singapore & \\
\hline
\end{tabular}




\begin{tabular}{|c|c|c|c|c|c|c|}
\hline & & & & & $\begin{array}{c}\text { University of } \\
\text { Social } \\
\text { Sciences } \\
\text { (SUSS) }\end{array}$ & \\
\hline \multicolumn{7}{|c|}{ Domain: Culture } \\
\hline \multicolumn{7}{|c|}{ Political Economic Considerations } \\
\hline \multirow{4}{*}{$\begin{array}{c}\text { Cultural } \\
\text { perspectives on } \\
\text { impact } \\
\text { investing }\end{array}$} & \multirow{4}{*}{ CAF 2016} & $\begin{array}{c}\text { World Giving } \\
\text { Index }\end{array}$ & \multirow{4}{*}{$\begin{array}{l}\text { Rank (high:1) } \\
\text { [Score \%] }\end{array}$} & $114[24]$ & $28[44]$ & $8[54]$ \\
\hline & & $\begin{array}{c}\text { Participation in: } \\
\text { Helping a } \\
\text { stranger } \\
\end{array}$ & & $138[25]$ & $79[50]$ & 33 [61] \\
\hline & & $\begin{array}{c}\begin{array}{c}\text { Donating } \\
\text { money }\end{array} \\
\end{array}$ & & 83 [23] & $19[58]$ & 7 [69] \\
\hline & & $\begin{array}{c}\text { Volunteering } \\
\text { time }\end{array}$ & & $55[23]$ & $54[23]$ & $22[33]$ \\
\hline \multirow[b]{2}{*}{ Social system } & \multirow{2}{*}{$\begin{array}{c}\text { Acemoglu \& } \\
\text { Robinson, } \\
\text { 2013; Global } \\
\text { Competitive } \\
\text { ness Index } \\
\text { (World } \\
\text { Economic } \\
\text { Forum, } \\
\text { 2016) } \\
\text { WGI (World } \\
\text { Bank, 2016) }\end{array}$} & $\begin{array}{c}\text { Political } \\
\text { institutions }\end{array}$ & $\begin{array}{c}\text { Inclusive or } \\
\text { extractive }\end{array}$ & Inclusive & Extractive & Inclusive \\
\hline & & $\begin{array}{l}\text { Economic } \\
\text { institutions }\end{array}$ & $\begin{array}{l}\text { Inclusive or } \\
\text { extractive }\end{array}$ & Inclusive & Inclusive & Inclusive \\
\hline \multicolumn{7}{|c|}{ Domain: Supports } \\
\hline \multicolumn{7}{|c|}{ Intermediaries $^{16}$} \\
\hline \multirow{9}{*}{\begin{tabular}{|c|} 
Funds \\
Independent \\
financial \\
advisors \\
Brokers, \\
dealers \\
Commercial \\
banks \\
Investment \\
banks \\
Social banks \\
Social \\
investment \\
wholesale \\
banks \\
CDFIs \\
Social \\
exchanges \\
Crowdfunding \\
platforms and \\
funds
\end{tabular}} & \multirow{9}{*}{$\begin{array}{c}\text { AVPN } \\
\text { (Mohan et } \\
\text { al., 2017); } \\
\text { Japan NAB, } \\
\text { 2016; UK } \\
\text { NAB, 2014; } \\
\text { Social } \\
\text { Investment } \\
\text { Forum, } \\
\text { 2017; } \\
\text { keyword } \\
\text { research }\end{array}$} & \multirow{9}{*}{$\begin{array}{l}\text { Asset managers } \\
\text { Incubators } \\
\text { Accelerators } \\
\text { Capacity } \\
\text { builders } \\
\text { Consulting } \\
\text { support }\end{array}$} & \multirow{9}{*}{--} & Arun LLC & $\begin{array}{c}\text { Milaap } \\
\text { Social } \\
\text { Ventures (SG) } \\
\end{array}$ & $\begin{array}{c}\text { Arts } \\
\text { Impact Fund }\end{array}$ \\
\hline & & & & Ashoka Japan & $\begin{array}{c}\text { National } \\
\text { Council of } \\
\text { Social Service } \\
\end{array}$ & $\begin{array}{r}\text { Big } \\
\text { Society } \\
\text { Capital } \\
\end{array}$ \\
\hline & & & & $\begin{array}{l}\text { Entrepreneurial } \\
\text { Training for } \\
\text { Innovative } \\
\text { Communities }\end{array}$ & $\begin{array}{c}\text { NUS Asia } \\
\text { Centre for } \\
\text { Social } \\
\text { Entrepreneurs } \\
\text { hip and } \\
\text { Philanthropy } \\
\end{array}$ & $\begin{array}{l}\text { Bridges } \\
\text { Ventures }\end{array}$ \\
\hline & & & & Hub Tokyo & raiSE & CAN \\
\hline & & & & Impact Hub & $\begin{array}{l}\text { Singapore } \\
\text { International } \\
\text { Foundation } \\
\end{array}$ & $\mathrm{CDC}$ \\
\hline & & & & $\begin{array}{c}\text { Japan Sustainable } \\
\text { Investment Forum } \\
\text { (JSIF) }\end{array}$ & $\begin{array}{l}\text { Tech For } \\
\text { Good }\end{array}$ & CAF \\
\hline & & & & $\begin{array}{c}\text { Japan Venture } \\
\text { Philanthropy Fund } \\
\end{array}$ & $\begin{array}{r}\text { The Impact } \\
\text { Hub Singapore } \\
\end{array}$ & ClearlySo \\
\hline & & & & Mistletoe & Tote Board & $\begin{array}{l}\text { FSE } \\
\text { Group }\end{array}$ \\
\hline & & & & NPO Edge & $\begin{array}{c}\text { Tsao } \\
\text { Foundation }\end{array}$ & $\begin{array}{c}\text { Impact } \\
\text { Ventures UK } \\
\text { (IVUK) }\end{array}$ \\
\hline
\end{tabular}

${ }^{16}$ The list of intermediaries is not exhaustive. In addition, some organizations might function across the categories. 


\begin{tabular}{|c|c|c|c|c|c|c|}
\hline & & & & NPO ETIC & & $\begin{array}{l}\text { Investing } \\
\text { For Good }\end{array}$ \\
\hline & & & & $\begin{array}{l}\text { Social Business } \\
\text { Network }\end{array}$ & & $\begin{array}{c}\text { Mårten } \\
\text { Wetterberg }\end{array}$ \\
\hline & & & & $\begin{array}{c}\text { Social Innovation } \\
\text { Park } \\
\end{array}$ & & NESTA \\
\hline & & & & $\begin{array}{l}\text { w Social Venture } \\
\text { Partners Tokyo }\end{array}$ & & $\begin{array}{l}\text { w Social } \\
\text { Finance }\end{array}$ \\
\hline & & & & NPO Banks: & DBS Bank & $\begin{array}{r}\text { Big } \\
\text { Society } \\
\text { Capital } \\
\end{array}$ \\
\hline & & $\begin{array}{c}\text { Financial } \\
\text { intiat }\end{array}$ & & $\begin{array}{c}\text { Community } \\
\text { Youth Bank Momo }\end{array}$ & $\begin{array}{c}\text { Community } \\
\text { Development } \\
\text { Council } \\
\text { (CDC) } \\
\end{array}$ & CAF Bank \\
\hline & & $\begin{array}{l}\text { Impact } \\
\text { investing, } \\
\text { Community }\end{array}$ & & Mirai Bank & $\begin{array}{c}\text { Community } \\
\text { Foundation of } \\
\text { Singapore } \\
\end{array}$ & $\begin{array}{l}\text { Charity } \\
\text { Bank }\end{array}$ \\
\hline & & $\begin{array}{l}\text { development } \\
\text { institutions }\end{array}$ & & $\begin{array}{l}\text { Community } \\
\text { Foundations: }\end{array}$ & $\begin{array}{l}\text { Tan Chin } \\
\text { Tuan } \\
\text { Foundation }\end{array}$ & $\begin{array}{l}\text { Community } \\
\text { Development } \\
\text { Finance } \\
\text { Association } \\
\text { (CDFA) } \\
\end{array}$ \\
\hline & & & & $\begin{array}{l}\text { The Sanaburi } \\
\text { Foundation }\end{array}$ & & $\begin{array}{l}\text { Triodos } \\
\text { Bank }\end{array}$ \\
\hline & & $\begin{array}{c}\text { Social } \\
\text { exchanges }\end{array}$ & -- & -- & IIX & SSX \\
\hline & & & & $\begin{array}{l}\text { Aizu Solar Citizen } \\
\text { Fund } \\
\end{array}$ & Crowdo & Crowdfunder \\
\hline & & & & Give2Asia & Give2Asia & CrowdPatch \\
\hline & & $\begin{array}{l}\text { Crowdfunding } \\
\text { and fundraising } \\
\text { platforms and }\end{array}$ & -- & $\begin{array}{c}\text { Kanagawa } \\
\text { Children's Future } \\
\text { Fund } \\
\end{array}$ & GiveAsia & Crowdshed \\
\hline & & funds & & & Giving.sg & Ethex \\
\hline & & & & & Indiegogo & Hubbub \\
\hline & & & & & Milaap & $\begin{array}{r}\text { JustGiving } \\
\text { Crowdfundin } \\
\mathrm{g} \\
\end{array}$ \\
\hline Networks and P & latforms & & & & & \\
\hline & & & & ANDE Japan & AVPN & $\begin{array}{l}\text { Edinburgh } \\
\text { Social } \\
\text { Enterprise }\end{array}$ \\
\hline & & & & AVPN & $\mathrm{BoP} \mathrm{Hub}$ & EngagedX \\
\hline Impact & $\begin{array}{c}\text { AVPN } \\
\text { (Mohan et }\end{array}$ & Fyamples & & $\begin{array}{c}\text { British Council } \\
\text { East Asia and China } \\
\text { region } \\
\end{array}$ & BRIDGE & EVPA \\
\hline $\begin{array}{l}\text { networks e.g. } \\
\text { Investors/Soci } \\
\text { al enterprises }\end{array}$ & $\begin{array}{c}\text { Japan NAB, } \\
2016 ; \\
\text { keyword }\end{array}$ & $\begin{array}{l}\text { networks and } \\
\text { platforms }\end{array}$ & -- & GIIN & $\begin{array}{c}\text { British } \\
\text { Chamber of } \\
\text { Commerce }\end{array}$ & GIIN \\
\hline & research & & & JFRA & $\begin{array}{c}\text { CSR Asia } \\
\text { (Singapore) }\end{array}$ & $\begin{array}{c}\text { Global } \\
\text { Social } \\
\text { Entrepreneur } \\
\text { ship Network } \\
\text { (GSEN) } \\
\end{array}$ \\
\hline & & & & JSIF & Family & Social \\
\hline
\end{tabular}




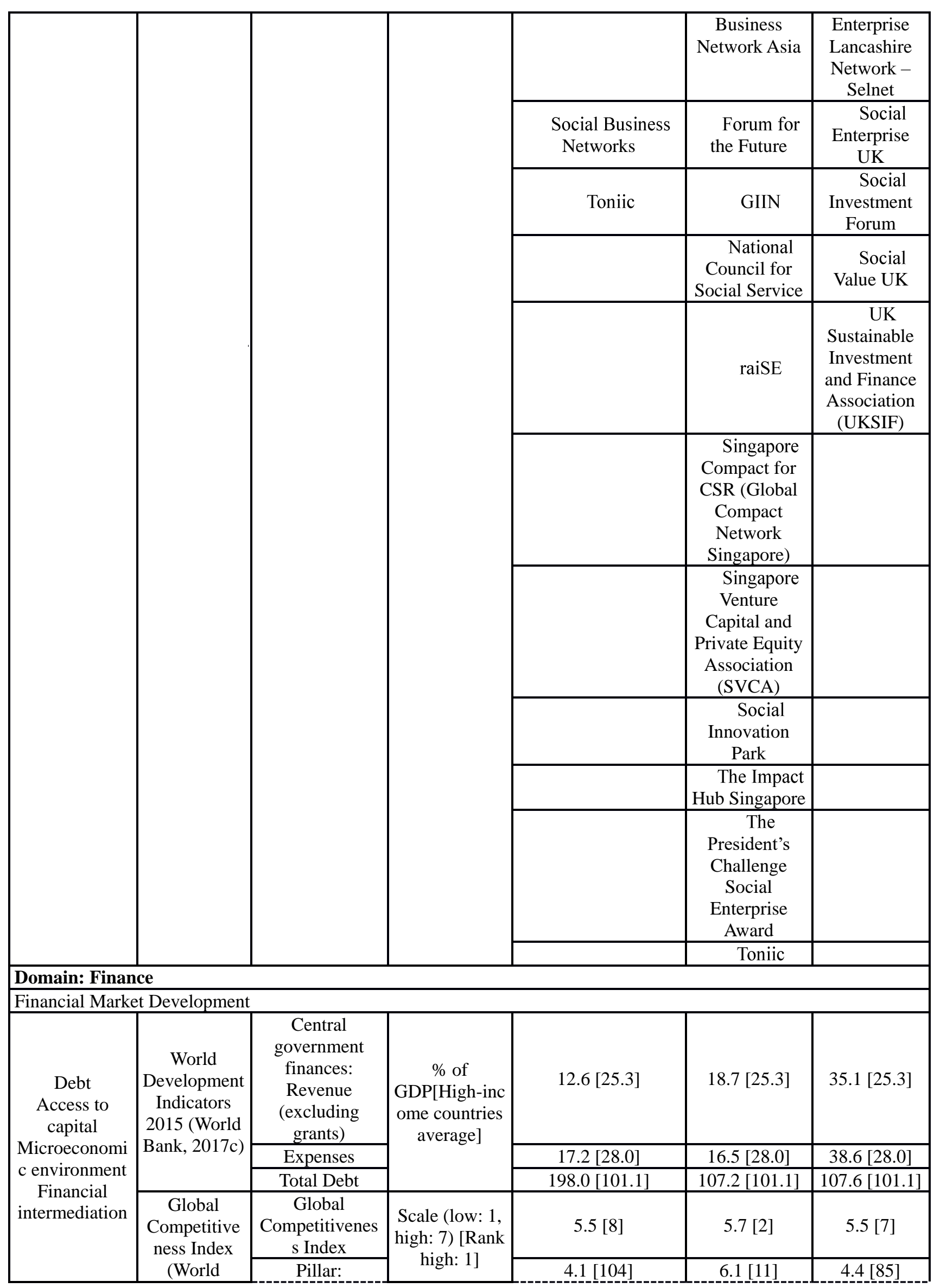




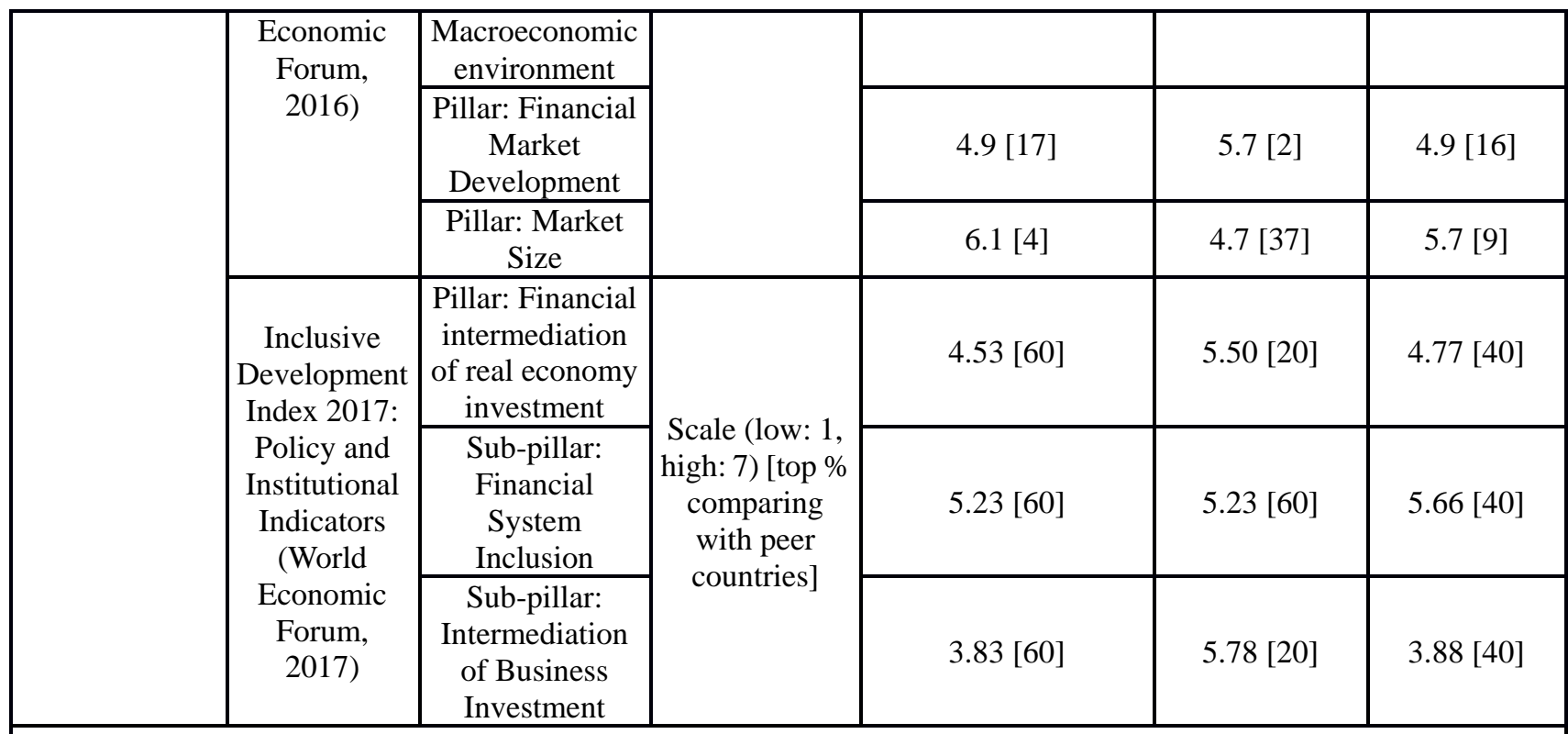

Source: Authors

\section{Copyrights}

Copyright for this article is retained by the author(s), with first publication rights granted to the journal.

This is an open-access article distributed under the terms and conditions of the Creative Commons Attribution license (http://creativecommons.org/licenses/by/4.0/). 